\title{
Iowa History and Culture: A Bibliography of Materials Published from 1987 through 1991 Part 3
}

\section{COMPILED BY PATRICIA N. DAWSON}

THIS BIBLIOGRAPHY completes the listing of works on Iowa history and culture published during the years 19871991. Two previous installments appeared in the Spring and Summer 1993 issues. This bibliography supplements the book, Iowa History and Culture: A Bibliography of Materials Published Between 1952 and 1986, compiled by David Hudson and I and published in 1989 by the State Historical Society of Iowa in association with Iowa State University Press. Subject arrangement of this listing follows closely the organization of the 1989 book. Brief annotations are included when the subject classification or title do not sufficiently reveal the nature of the material. Included in this list are a few items published earlier than 1987 that escaped us in the compilation of the 1989 book.

I would like to thank David Hudson and Earl Rogers of the University of Iowa for invaluable assistance in retrieving citations, and the staff at the State Historical Society of Iowa for clarification of some material. The Annals of Iowa 52 (Fall 1993). (C) The State Historical Society of Iowa, 1993.

THE ANNALS OF IOWA 52 (Fall 1993). CThe State Historical Society of Iowa, 1993. 


\section{GOVERNMENT AND POLITICS}

\section{Iowa and the Federal Government}

Hoover, Herbert. American Individualism and The Challenge to Liberty. West Branch: Herbert Hoover Presidential Library Association, 1989. 219 pp. Reprint of two essays originally published in 1922 and 1934.

Kirkendall, Richard S. "Henry A. Wallace's Turn Toward the New Deal, 1921-1924." Annals of Iowa 49 (Winter/Spring 1988), 221-39.

Malone, Laurence Joseph. "Opening the West: Federal Internal Improvements before 1860." Ph.D. diss., New School for Social Research, 1991. 275 pp.

Margulies, Herbert F. "Senate Moderates in the League of Nations Battle: The Case of Albert B. Cummins." Annals of Iowa 50 (Spring 1990), 333-58.

- "The Moderates in the League of Nations Battle: The Case of William S. Kenyon." Midwest Review 12 (1990), 16-33.

Morrison, Dennis L. "Henry A. Wallace and Democratic Party Politics, 1940-1946." M.A. thesis, University of Houston-Clear Lake, 1989. $122 \mathrm{pp}$.

Radosh, Ronald. "The Economic and Political Thought of Henry A. Wallace." M.A. thesis, University of Iowa, 1960. 175 pp.

Warner, Gale, and Michael Shuman. "The Iowa Connection: John Chrystal." In Citizen Diplomats: Pathfinders in Soviet-American Relations and How You Can Join Them, 103-30. New York: Continuum, 1987. $381 \mathrm{pp}$.

\section{State Government}

Caldeira, Gregory A., and Samuel C. Patterson. "Contours of Friendship and Respect in the Legislature." American Politics Quarterly 16 (1988), 466-85.

- "Political Friendship in the Legislature." Journal of Politics 49 (1987), 953-75.

Carter, Brian. State Government in Iowa. 5th ed. Iowa City: Institute of Public Affairs, University of Iowa, 1990. $98 \mathrm{pp}$.

Constitution of the State of Iowa: With History and Amendments. Des Moines: Secretary of State, 1990.

Cook, Rhodes. "Iowa Remapping Goes Smoothly as Six Districts Become Five." Congressional Quarterly Weekly Report 49 (18 May 1991), 1306-8. 
Donovan, Beth. "Iowa: Reshuffling the Deck." Congressional Quarterly Weekly Report 49 (21 December 1991), 3719. 1990 reapportionment.

Harmon, Robert B. Government and Politics in Iowa: A Selected Guide to Information Sources. Monticello, IL: Vance Bibliographies, 1990. $20 \mathrm{pp}$.

Swenson, David. A Decade of Adjustment: Economic, Social, and Political Forces Influencing Iowa Government Policy in the 1980s. Iowa City: Institute of Public Affairs, University of Iowa, 1988. 129 pp.

\section{Local Government}

Belgum David. Memoirs of Iowa's Only Socialist Mayor. Iowa City: Rose of Sharon Publishing House, 1990. 74 pp.

Ogle, Maureen. "Efficiency and System in Municipal Services: Fire Departments in Iowa, 1870-1890." Annals of Iowa 50 (Spring 1991), 841-60.

- "Redefining 'Public' Water Supplies, 1870-1890: A Study of Three Iowa Cities." Annals of Iowa 50 (Summer 1990), 507-30.

Otto, Daniel M., and Mark A. Edelman. "Innovation in Structural Change of Local Government." American Journal of Agricultural Economics 72 (November 1990), 1074-80. Iowa, 1980s.

\section{Politics}

Barone, Michael, and David R. Gergen. "Abortion Politics." U.S. News and World Report 108 (18 June 1990), 27.

Blumenthal, Sidney. "The Primal Scream: Tom Harkin and the Democratic Id." New Republic 205 (21 October 1991), 22-24.

Briley, Ron. "Insurgency and Political Realignment: Regionalism and the Senatorial Elections of 1922 in Iowa, Nebraska, North Dakota, and Minnesota." Mid-America 72 (January 1990), 49-69.

Brookhiser, Richard. "Lazy Days, Busy Pols." National Review 42 (23 July 1990), 22-23. Tom Tauke-Tom Harkin Senate campaign.

Clift, Eleanor, and John McCormick. "Liberal and Proud of It: Iowa's 'Prairie Populist': Tom Harkin Is Itching to Take on President Bush." Newsweek 118 (26 August 1991), 22-23.

Colbert, Thomas B. "Disgruntled 'Chronic Office Seeker' or Man of Political Integrity: James Baird Weaver and the Republican Party in Iowa, 1857-1877." Annals of Iowa 49 (Winter/Spring 1988), 187-207. 
Cook, Rhodes. "The Agrarian Economy and Iowa Politics." Congressional Quarterly Weekly Report 47 (16 September 1989), 2430.

Cook, Robert J. "Puritans, Pragmatists, and Progress: The Republican Coalition in Iowa, 1854-1878." D.Phil. thesis, St. Catherine's College, Oxford University, 1986. 324 pp.

Doherty, Steven J. "The Politics of the 1987 lowa Groundwater Protection Act." M.A. thesis, Iowa State University, 1990. 105 pp.

Donovan, Beth. "Avenson Set to Face Branstad with Abortion as Key Issue." Congressional Quarterly Weekly Report 48 (9 June 1990), 1810-11.

- . "Democrats Tug on GOP Roots as Iowa Adapts to New Times." Congressional Quarterly Weekly Report 49 (17 August 1991), 2288-92.

- "Open 2nd District Contest Tests Partisan Trends." Congressional Quarterly Weekly Report 48 (7 April 1990), 1089-92.

“Ethics Complaint Hits Tauke Note." Congressional Quarterly Weekly Report 47 (8 July 1989), 1681.

Finlay, Mark R. "Dashed Expectations: The Iowa Progressive Party and the 1948 Election." Annals of Iowa 49 (Summer 1988), 329-48.

Gelfand, Lawrence E., and Dennis Deslippe, eds. Constitutional Issues in the Twentieth Century of Special Interest to Iowans. Iowa City: Center for the Study of the Recent History of the United States, 1989. $112 \mathrm{pp}$. Book version of the Annals of Iowa 50 (Summer 1989).

Graney, Glen. "Negative Nussle-Tabor Match Is Turning Off Voters. " Congressional Quarterly Weekly Report 48 (27 October 1990), 3641-42.

Harkin, Tom, with C. E. Thomas. Five Minutes to Midnight. Secaucus, NJ: Carol Publishing Group, 1990. 383 pp. Political agenda with regard to the arms race.

“Jim Nussle, R-Iowa 2." Congressional Quarterly Weekly Report 48 (10 November 1990), 3812. Profile of the House freshman.

Kaplan, Dave. "The Winter of their Content: Farmers' 1990 Attitudes." Congressional Quarterly Weekly Report 48 (17 March 1990), 850-51.

Lause, Mark A. "Voting Yourself a Farm in Antebellum Iowa: Towards an Urban, Working-class Prehistory of the Post-Civil War Agrarian Insurgency." Annals of Iowa 49 (Winter/Spring 1988), 169-86.

Lisowski, Lori A. "Guardians of Inseparable Union: Politics, Civil War, and Victory in Polk County, Iowa." Ph.D. diss., University of Southern California, 1991. 
McDaniel, George William. "New Era Agrarian Radicalism: Smith W. Brookhart and the Populist Critique." Annals of Iowa 49 (Winter/Spring 1988), 208-20.

- "The Republican Party in Iowa and the Defeat of Smith Wildman Brookhart, 1924-1926." Annals of Iowa 48 (Winter/ Spring 1987), 413-34.

- "The Search for Smith Wildman Brookhart: A Pilgrim's Progress." Books at Iowa 52 (April 1990), 53-70.

Mahtesian, Charles. "Iowa: An Incumbent vs. Incumbency." Congressional Quarterly Weekly Report 49 (21 December 1991), 3724 .

Mashek, John. "Where's the Voter Revolt in the Midwest?" U.S. News and World Report 101 (22 September 1986), 26-28.

Mather, George B. The Short Ballot in Iowa. Occasional Research Papers, no. 6. Iowa City: Division of Continuing Education, University of Iowa, 1987. $47 \mathrm{pp}$.

Osbun, Lee Ann, and Steffen W. Schmidt, eds. Issues in Iowa Politics. Ames: Iowa State University Press, 1990. 276 pp.

Ostler, Jeffrey D. "The Fate of Populism: Agrarian Radicalism and State Politics in Kansas, Nebraska, and Iowa, 1880-1892." Ph.D. diss., University of Iowa, 1990. 487 pp.

Pratt, William C. "The Farmers Union and the 1948 Henry Wallace Campaign." Annals of Iowa 49 (Summer 1988), 349-70.

Roberts, Charles W. "When the Candidates Came to Town." Iowan 37 (Fall 1988), 28-32, 52-55. When Franklin Roosevelt and Alf Landon met in Des Moines for a drought conference, 1936.

Shapiro, Bruce. "Focus on the State Races." Nation 251 (12 November 1990), 551-54.

Steinke, Gary W. "The Dynamics of Political Change: Electoral Behavior in Iowa, 1880-1980." M.A. thesis, Drake University, 1983. 127 pp.

"Tom-Tom." Economist 317 (6 October 1990), 26-27. Tom Harkin and Tom Tauke.

Weisberg, Jacob. "The Corn Is High." New Republic 203 (12 November 1990), 12-14. U.S. Senate campaign in Iowa, 1990.

\section{Iowa Caucuses and Campaign ' 88}

“Advantage, Bush." Economist 306 (20 February 1988), 11. Editorial on George Bush winning in the Iowa caucuses.

"Appointment in Iowa." Economist 306 (6 February 1988), 11-12.

Barnes, Fred. "Charade on Main Street: Dog-and-Pony Show in Iowa." New Republic 196 (15 June 1987), 15-17. 
—. "The Sprint." New Republic 198 (8 February 1988), 12-13. Democrats in Iowa, campaign 1988.

Barrett, Laurence I. "With Minds of Their Own: Iowa Voters Like the Reagan Era Less Than Most Americans." Time 131 (25 January 1988), 23.

Borger, Gloria, and Andy Plattner. "Campaign '88: Why Iowa Is Bad for American Politics." U.S. News and World Report 103 (6 July 1987), 22-24.

Brownstein, Ronald. "Making Hay in Iowa." New York Times Magazine 137 (29 November 1987), S54.

Buell, Emmett H., Jr. “First-in-the-Nation: Disputes Over the Timing of Early Democratic Presidential Primaries and Caucuses in 1984 and 1988." Journal of Law and Politics 4 (1987), 311-42.

Cockburn, Alexander. "In Black and White." New Statesman 115 (18 March 1988), 20-21. Presidential race and Jesse Jackson.

Colford, Steven W. "Babbitt Ads Spring Up Early in Iowa." Advertising Age 58 (11 May 1987), 39.

Colt, George H. "Cornfield Kingmakers: An Iowa Couple Searches Intently for the Next President." Life 11 (February 1988), 34-36. Jack and Shirley Tabor.

Cook, Rhodes. "In Iowa, Look for Clues Behind the Hoopla." Congressional Quarterly Weekly Report 46 (9 January 1988), 47-53.

-. "Iowa." Congressional Quarterly Weekly Report 46 (15 October 1988), 2900.

- "Iowa's Stars Take a Back Seat in New Hampshire." Congressional Quarterly Weekly Report 46 (13 February 1988), 287-90.

"Couple Duels in Iowa Race." Christianity Today 32 (5 February 1988), 54.

"Covering the Zone in Iowa: Journalists Threaten to Outnumber Voters in Midwest Bellwether." Broadcasting 114 (8 February 1988), 47-49.

Curry, Tom. "Faithful on the Move: The GOP Won't be the Same." Commonweal 114 (18 December 1987), 727-29.

“Cutting Iowa Down to Size." Economist 304 (22 August 1987), 21-22.

Drew, Elizabeth. "Letter from Washington." New Yorker 64 (7 March 1988), 99-111.

Duffy, Michael. "Planning a Secret-Poll Scam." Time 130 (23 November 1987), 27. Unauthorized straw ballot arranged by Richard Gephardt's campaign managers. 
Elving, Ronald D. “Iowa's Incumbents Coast: Redfern Will Tackle Nagle." Congressional Quarterly Weekly Report 46 (11 June 1988), 1593.

Gillespie, Elgy. "Iowa: Where Nobodies Become Somebodies." New Statesman 115 (5 February 1988), 17.

Greenfield, Meg. "Surprises-On Schedule." Newsweek 111 (22 February 1988), 80.

Gronbeck, Bruce. "Mythic Portraiture in the 1988 Iowa Presidential Caucus Bio-ads." American Behavioral Scientist 32 (March-April 1989), 351-64.

Hertzberg, Hendrik. "First Returns." New Republic 198 (29 February 1988), 43.

"How Many Iowans Does it Take to Hold a Caucus?" People Weekly 29 (8 February 1988), 56. Charles and Harriet Moore.

Hoyt, Michael. "Exploring Caucus Country: The Candidates Are Crisscrossing the State, and the National Media Are Moving In, But, in Iowa, It's the Local Press that Counts." Columbia Journalism Review 26 (January-February 1988), 29-35.

"Iowa and After." National Review 40 (4 March 1988), 16-17.

"Iowa Speaks." Economist 306 (13 February 1988), 23-24.

Kaus, Mickey. "Far Too Much Ado about Little Iowa." Newsweek 110 (6 July 1987), 20-21.

_. "Throwing the 'Long Bomb.'" Newsweek 109 (8 June 1987), 20. Pete $d u$ Pont debates Bruce Babbitt in Iowa.

Kaus, Mickey, and Eleanor Clift. "All of Us Are Sinners." Newsweek 111 (25 January 1988), 16-17.

Kaus, Mickey, Howard Fineman, and John McCormick. "Adventures in Campaignland." Newsweek 111 (1 February 1988), 18-23.

Klein, Joe. "The First Cut: Iowa May Elevate a Dwarf or Two." New York 21 (8 February 1988), 32-36.

. ${ }^{\circ H o g}$ Haven: Jesse Jackson Cultivates the Farm Vote in Iowa." New York 20 (7 September 1987), 42-45.

Kopkind, Andrew. "Gimme Some Spin." Nation 246 (20 February 1988), 220-21.

- . "A Populist Message Hits Home: Jackson in Iowa." Nation 245 (18 July 1987), 37-41.

- "Strategic Shift to the Left." Nation 246 (6 February 1988), $145-47$.

Kramer, Michael. "The Tortoise and the Hare." U.S. News and World Report 104 (8 February 1988), 14-16. 
Lawton, Kim A. "Iowa Christians and the Race for the Oval Office." Christianity Today 32 (15 January 1988), 50, 52, 55.

McDonald, Marci. “Iowa's Campaign Circus." Maclean's 101 (1 February 1988), 18-19.

_- "Working Miracles in Snowbound Iowa." Maclean's 101 (8 February 1988), 22-23.

McGinnis, Tim. "Sioux City Sue's Farm Journal." Nation 246 (13 February 1988), 198-99. Facetious account of presidential candidates in Iowa.

Morganthau, Tom. "Turmoil on the Right: Dole's Challenge and Robertson's Rise Point to a Major Upheaval for the GOP." Newsweek 111' (22 February 1998), 14-18.

“Only 331 Campaigning Days till the Iowa Caucuses." Economist 302 (14 March 1987), 25-26.

Palmer, Stacy E. “Drake Scholar a Rare In-State Critic of Iowa Caucuses." Chronicle of Higher Education 34 (3 February 1988), A3. Hugh Winebrenner.

Plattner, Andy. "Campaign Diary: Bruce Babbitt." U.S. News and World Report 104 (15 February 1988), 25-28.

- "Making Hay in Iowa." U.S. News and World Report 103 (31 August 1987), 20.

- "What Isn't Working in Iowa." U.S. News and World Report 104 (11 January 1988), 25-26.

Plattner, Andy, and Harrison Rainie. "The Madness of Iowa: Is Anybody Listening?" U.S. News and World Report 104 (25 January 1988), 28-30.

"Playing Switch and Bait in Iowa." U.S. News and World Report 104 (1 February 1988), 22.

"Political Ad Spending Up in lowa Compared to 1984." Broadcasting 114 (18 January 1988), 72, 74-77.

Ridout, Christine F. "The Role of Media Coverage of Iowa and New Hampshire in the 1988 Democratic Nomination." American Politics Quarterly 19 (1991), 43-58.

Shapiro, Walter. "Battling for the Post-liberal Soul." Time 131 (22 February 1988), 19-20.

_. "The Folks with the First Say." Time 131 (25 January 1988), 12-17.

- "Getting to Know Them: What the Iowa Campaign Revealed about the Candidates." Time 131 (8 February 1988), 28-30.

Sidey, Hugh. "Hot Air-and Hope-for Iowa." Time 130 (10 August 1987), 13. 
—_. "It Seems to Work.'" Time 131 (25 January 1988), 10-11.

—_. "Jackson Sets up Shop." Time 130 (7 September 1987), 20.

18. "Watching from the Warmth." Time 131 (22 February 1988),

Squire, Peverill, ed. The Iowa Caucuses and the Presidential Nominat-

ing Process. Boulder, CO: Westview Press, 1989. 189 pp.

"Straws from Iowa." Nation 246 (20 February 1988), 219-20.

"When Iowa Becomes Brigadoon." Economist 306 (9 January 1988), 21-22.

Wieland, Leo. "The Importance of Iowa." World Press Review 35 (February 1988), 20.

Will, George. "The Rheostat Rule-and More." Newsweek 111 (15 February 1988), 84.

64.

Winebrenner, Hugh. The Iowa Precinct Caucuses: The Making of a Media Event. Ames: Iowa State University Press, 1987. 184 pp.

"A Winnowing of Democrats." Economist 306 (13 February 1988), 24-26.

\section{IMMIGRATION AND ETHNIC GROUPS}

\section{General}

Brose, David A. "Ethnographic Crossroads: Iowa as a Cultural Conduit." Palimpsest 72 (Winter 1991), 176-91.

Fargo, O. J., ed. Iowa Immigrants. Creston: Green Valley AEA, 1988. $51 \mathrm{pp}$.

Goudy, Willis, and Rogelio Saenz. Detailed Ancestry Categories for the State of Iowa. Ames: Cooperative Extension Service, Iowa State University, 1983. 4 pp.

Saenz, Rogelio, Willis Goudy, and Nak Hoon Lee. Minority Groups in Iowa. Ames: Cooperative Extension Service, Iowa State University, 1987. $74 \mathrm{pp}$.

Schenken, Suzanne $O$. "The Immigrants' Advocate: Mary Treglia and the Sioux City Community House, 1921-1959." Annals of lowa 50 (Fall 1989/Winter 1990), 181-213.

\section{African-Americans}

Beran, Janice A. "Diamonds in Iowa: Blacks, Buxton, and Baseball." Journal of Negro History 75 (Summer-Fall 1990), 81-95. 
Breitweiser, Diane, Emily Henderson, Shirlee Johnson, Clifford Moore, and R. Richard Rice. "Analysis of Black News in Four Iowa Newspapers." M.S.W. project, University of Iowa, 1970. $94 \mathrm{pp}$.

Cantor, George. Historic Black Landmarks: A Traveler's Guide. Detroit: Visible Ink Press, 1991. 372 pp. Includes Fort Des Moines and Simpson College.

.Hewitt, William L. "So Few Undesirables: Race, Residence, and Occupation in Sioux City, 1890-1925." Annals of Iowa 50 (Fall 1989/Winter 1990), 158-79.

Report of the Iowa Commission on the Status of Blacks to the Governor of Iowa and the State Legislature, Fiscal Year 1988-89. Des Moines, 1989. $7 \mathrm{pp}$.

Report of the Iowa Commission on the Status of Blacks to the Governor of Iowa and the State Legislature, Fiscal Year 1989-90. Des Moines, 1990. 14 pp.

Stromquist, Shelton. "Intersections of Race and Class: Coal Miners and Their Communities, a Review Essay." Annals of Iowa 49 (Fall 1988), 501-5. Buxton.

Van Dusseldorp, Jon Karl. "Newspaper Coverage of Racial News: An Iowa Case Study." M.A. thesis, University of Iowa, 1968. 95 pp. News about African-Americans in the Des Moines Register, 1960-1966.

White, Maude E. "A Sociological Inquiry into Black Leadership in Des Moines." M.A. thesis, Drake University, 1972. 125 pp.

\section{Asians}

Baccam, InNgeun, interviewer. Refugee Oral History. Translated by Siang Bacthi, edited by Jack Lufkin. Des Moines: Tai Studies Center, n.d. 69 pp. Interviews with Tai Dam refugees in Des Moines.

Bacthi, Siang, InNgeun Baccam Soulinthavong, and Jack Lufkin. "So We Stayed Together: The Tai Dam Immigrate to lowa." Palimpsest 69 (Winter 1988), 163-72.

Bell, Sue E., and Michael B. Whiteford. “Tai Dam Health Care Practices: Asian Refugee Women in Iowa." Social Science and Medicine 24 (1987), 317-25.

Our Stories: A Collection of Writings by Luther's Cambodian, Laotian, and Vietnamese Students. Decorah: Luther College, 1986. 33 pp. 


\section{Czechs}

Chadima, Helen. "The Beseda: The Czech National Dance in Cedar Rapids, Iowa." Dance Research Journal 22 (Fall 1990), 23-28.

\section{Danes}

Hansen, Thorvald. "Preserving Danish-American History in the USA." In From Scandinavia to America, edited by Steffen E. Jorgensen, Lars Scheving, and Niels P. Stilling, 369-77. Odense University Studies in History and Political Science, 103. Odense: Odense University Press, 1987. Danish Immigrant Archives, Grand View College, Des Moines; and Danish Immigrant Museum, Elk Horn.

Mackintosh, Jette. "Danskere i Midtvesten [Danes in the Midwest]." Ph.D. diss., University of Copenhagen, 1990.

- . "Ethnic Patterns in Danish Immigrant Agriculture: A Study of Audubon and Shelby Counties, Iowa." Agricultural History 64 (Fall 1990), 59-77.

- "Little Denmark' on the Prairie: A Study of the Towns Elk Horn and Kimballton in Iowa." Journal of American Ethnic History 7 (Spring 1988), 46-68.

- "Migration and Mobility among Danish Settlers in Southwest Iowa." Journal of Historical Geography 17 (April 1991), 165-89.

Scheving, Lars. "Dannevirke-A Religious Newspaper of a Danish Minority, 1884-1904." In From Scandinavia to America, edited by Steffen E. Jorgensen, Lars Scheving, and Niels P. Stilling, 320-35. Odense University Studies in History and Political Science, 103. Odense: Odense University Press, 1987.

- "Dannevirke-en dansk-amerikansk avis: Holdning og rolle, 1884-1904." Master's thesis, University of Copenhagen, 1982.

\section{Dutch}

Brunckhorst, Louis A. "A Study of the Degree of Acculturation of the Dutch-American Community of Pella, Iowa." M.A. thesis, Drake University, 1956. 102 pp.

Doyle, Richard L. "A Comparison of Economic Development and Wealth Mobility in the Dutch Colonies of Pella, Iowa, and Holland, Michigan, 1850-1880.". Ethnic Forum 7 (1987), 49-63.

Webber, Philip E. Pella Dutch: The Portrait of a Language and Its Use in One of Iowa's Ethnic Communities. Ames: Iowa State University Press, 1988. $174 \mathrm{pp}$. 


\section{Germans}

Polansky Schneller, Paul. "Migration of Bukovina Germans to North America." Journal of the American Historical Society of Germans from Russia 11 (1988), 27-34. Migration to Iowa, 1900-1910.

Schmidt, Nikolaus. "Hans Reimer Claussen: Ein 'Achtundvierziger' in Amerika, 1804-1873." M.A. thesis, Ruprecht-KarlsUniversitats, 1989. $107 \mathrm{pp}$.

\section{Hungarians}

Vassady, Béla. "New Buda: A Colony of Hungarian Forty-eighters in Iowa." Annals of Iowa 51 (Summer 1991), 26-52.

\section{Irish}

Fitzgerald, Margaret E. The Uncounted Irish in Canada and the United States. Toronto: P. D. Meany Publishers, 1990. 377 pp. Includes a chapter on the Irish in Iowa.

\section{Latvians}

Rostocks, Mara. "An Investigation of the Assimilation of Latvian Immigrants in the Greater Des Moines Area." M.A. thesis, Drake University, 1967. 77 pp. 1948-1966.

\section{Mexicans}

Davis, Marilyn P. Mexican Voices/American Dreams: An Oral History of Mexican Immigrants to the United States. New York: $\mathrm{H}$. Holt, 1990. 446 pp. Includes interviews at Lone Tree and Muscatine.

\section{Norwegians}

Christianson, J. R., ed. and trans. "A Letter of 1852 from Eldorado." Norwegian-American Studies 32 (1989), 149-56. Letter from Bertel Osuldsen describing life in Norwegian settlement in northeastern Iowa.

Floystad, Ingeborg. “Kvinnene i det (ville) vesten [Women in the (wild) west]." Historisk Tidsskrift 66 (1987), 209-22. Norwegian women settlers in the West and Midwest.

Johnson, Steven L., and Marion J. Nelson. "Immigrant DynamicsThe Jacobson Farmstead." Norwegian-American Studies 32 (1989), 93-117. Decorah farmstead donated to Vesterheim, the Norwegian-American Museum. 
Nelson, Marion. Vesterheim: Samplings from the Collection. Photographs by Darrell Henning. Decorah: Norwegian-American Museum, 1973. 27 pp.

Norway in America: Four Exhibitions Invited from Vesterheim for Showing in Hamar, Lillehammer, Gjovik, May 13-August 27, 1989.

Decorah: Vesterheim, 1989. $110 \mathrm{pp}$.

Rosendahl, Peter J. More han Ola og han Per. Edited by Einar Haugen and Joan N. Buckley. Iowa City: University of Iowa Press, 1988. 167 pp. Cartoon strips first published 1926-1935 reproduced in a bilingual Norwegian/English edition.

\section{Swedes}

Cain, Betty S. American from Sweden: The Story of A. V. Swanson. Carbondale: Southern Illinois University Press, 1987. 99 pp. Ames merchant who emigrated in 1911.

Nordquist, Kjell. "Destination-Oskaloosa." Swedish American Genealogist 8 (June 1988), 57-66.

Sonquist, Linnea Swanson. "Nea Recalls." Swedish-American Historical Quarterly 39 (April 1988), 21-38. Letters describing Iowa childhood in Boxholm.

Winsberg, Morton D. “The Changing Relative Location of the Swedish-Born in the United States, 1850-1980." SwedishAmerican Historical Quarterly 38 (October 1987), 160-66.

\section{Welsh}

Davies, Phillips G. "The Growth and Assimilation of the Welsh Settlements in Iowa." Iowa State Journal of Research 60 (August 1985), 107-28.

\section{AMERICAN INDIANS}

\section{Prehistoric}

Adair, Mary J. Prehistoric Agriculture in the Central Plains. University of Kansas Publications in Anthropology 16. 1988. 145 pp. Includes southwestern Iowa.

— . "Prehistoric Cultivation in the Central Plains: Its Development and Importance." Ph.D. diss., University of Kansas, 1984. $276 \mathrm{pp}$.

Anderson, Duane C. "Toward a Processual Understanding of the Initial Variant of the Middle Missouri Tradition: The Case of 
the Mill Creek Culture of Iowa." American Antiquity 52 (1987), 522-37.

Anderson, Duane C., and Joseph A. Tiffany. "A Caddoan Trade Vessel from Northwestern Iowa." Plains Anthropologist 32 (1987), 93-96.

Anfinson, Scott F. "The Prehistory of the Prairie Lake Region in the Northeastern Plains." Ph.D. diss., University of Minnesota, 1987. 371 pp. North central Iowa.

Benn, David W. "Another View of the Hanging Valley Site." Plains Anthropologist 34 (1989), 179-81. West central lowa.

ed. Woodland Cultures on the Western Prairies: The Rainbow Site Investigations. Report 18. Iowa City: Office of the State Archaeologist, University of Iowa, 1990. 256 pp. Plymouth County site.

DeVore, Steven Leroy. Moingona Phase Oneota Subsistence Strategies: Examples from the Central Des Moines River Valley. Iowa City: Office of the State Archaeologist, 1990. $32 \mathrm{pp}$.

Glenwood Culture Paleoenvironment and Diet: Analysis of Plant and Animal Remains from the Wall Ridge Earthlodge (13ML176). Iowa City: Office of the State Archaeologist, 1990.

Green, William, ed. Archaeological and Paleoenvironmental Studies in the Turkey River Valley, Northeastern Iowa. Research Paper Series; vol. 13, no. 1. Iowa City: Office of the State Archaeologist, 1988. 293 pp.

Gribbin, Mary, and John Gribbin. "Where Buffalo Roam...." Analog Science Fiction/Science Fact 110 (October 1990), 60-65. Mill Creek culture of northwest lowa.

Hughes, R. E., and F. W. Nelson. "New Findings on Obsidian Source Utilization in Iowa." Plains Anthropologist 32 (1987), 313-16.

Miller, Terry. "Prehistoric Exchange and Lithic Utilization in Eastern Iowa." Plains Anthropologist 34 (1989), 205-22.

O'Bright, Jill York. The Perpetual March: An Administrative History of Effigy Mounds National Monument. Omaha: Midwest Regional Office, National Park Service, 1990. 278 pp.

Paleoenvironments and Archaeology of the Mississippi Valley in Southeastern Iowa: Association of the Iowa Archaeologists 1991 Field Trip Guide. N.p.: Association of the lowa Archaeologists, 1991.

Stoltman, James B. "Ceramic Petrography as a Technique for Documenting Cultural Interaction: An Example from the Upper Mississippi Valley." American Antiquity 56 (1991), 103-20. Analysis of two sites: Hartley Fort in northeastern Iowa and Fred Edwards site in southwestern Wisconsin. 
ed. Prehistoric Mound Builders of the Mississippi Valley: Proceedings of a Symposium Sponsored by the Putnam Museum, Davenport, Iowa, November 15-17, 1985. Davenport: Putnam Museum, 1986. $39 \mathrm{pp}$.

Theler, James L. Woodland Tradition Economic Strategies: Animal Resource Utilization in Southwestern Wisconsin and Northeastern Iowa. Iowa City: Office of the State Archaeologist, University of Iowa, 1987. $136 \mathrm{pp}$.

Tiffany, Joseph A. "Models of Mississippian Culture History in the Western Prairie Peninsula: A Perspective from Iowa." In Cahokia and the Hinterlands: Middle Mississippian Cultures of the Midwest, edited by Thomas E. Emerson and R. Barry Lewis, 183-92. Urbana: University of Illinois Press, 1991.

- "Preliminary Report on Excavations at the McKinney Oneota Village Site (13LA1), Louisa County, Iowa." Wisconsin Archeologist 69 (1988), 227-312.

\section{Historic}

Boelhower, William. "Saving Saukenuk: How Black Hawk Won the War and Opened the Way to Ethnic Semiotics." Journal of American Studies 25 (December 1991), 333-61.

Diedrich, Mark, comp. Winnebago Oratory: Great Moments in the Recorded Speech of the Hochungra, 1742-1887. Rochester, MN: Coyote Books, 1991. 106 pp.

Gourley, Kathryn E. "Locations of Sauk, Mesquakie, and Associated Euro-American Sites, 1832 to 1845: An Ethnohistoric Approach." M.A. thesis, Iowa State University, 1990. 281 pp. Sauk and Mesquakie villages, Indian agencies, trading houses, and military posts in Iowa.

Herring, Joseph B. "Presbyterian Ethnologists among the Iowa and Sac Indians, 1837-1853." American Presbyterians 65 (1987), 195-203.

Kurtz, Royce. "Timber and Treaties: The Sauk and Mesquakie Decision to Sell Iowa Territory." Forest and Conservation History 35 (April 1991), 56-64.

Laird, Allison. A Guide to Native American Artifacts in Iowa Hall. Iowa City: Office of the State Archaeologist 1989. $60 \mathrm{pp}$.

Phillips, Ruth B. "Clothed in Blessing: Meaning in Mesquakie Costume." Annals of Iowa 51 (Summer 1991), 1-25.

Schilz, Thomas F., and Jodye L. D. Schilz. "Beads, Bangles, and Buffalo Robes: The Rise and Fall of the Indian Fur Trade along the Missouri and Des Moines Rivers, 1700-1820." Annals of Iowa 49 (Summer/Fall 1987), 4-25. 
Swaim, Ginalie. "'Clothe Yourself in Fine Apparel': Mesquakie Costume in Word, Image, and Artifact." Palimpsest 72 (Summer 1991), 70-82.

Torrence, Gaylord. "A Mesquakie Drawing." Palimpsest 69 (Summer 1988), 64-68.

Torrence, Gaylord, and Robert Hobbs. Art of the Red Earth People: The Mesquakie of Iowa. Iowa City: University of Iowa Museum of Art, 1989. 144 pp.

\section{LAW AND CRIME}

Acton, Richard. "The Magic of Undiscouraged Effort: The Death Penalty in Early Iowa, 1838-1878." Annals of Iowa 50 (Winter 1991), 721-50.

- . "To Go Free." Palimpsest 70 (Summer 1989), 50-61. The case of Ralph, a former slave.

Bartels, Robert. Benefit of Law: The Murder Case of Ernest Triplett. Ames: Iowa State University Press, 1988. $162 \mathrm{pp}$. Murder of a Sioux City child, 1955 conviction, and 1972 reversal of that conviction.

Bauer, Patrick B. "Farm Mortgagor Relief Legislation in Iowa during the Great Depression." Annals of Iowa 50 (Summer 1989), 23-62.

- "Judicial Foreclosure and Statutory Redemption: The Soundness of Iowa's Traditional Preference for Protection over Credit." Iowa Law Review 71 (October 1985), 1-91. Farm mortgages, 1838-1985.

Beard, Jane. The Law and the Iowa Citizen. Cedar Falls: Iowa Division, American Association of University Women, [1966]. 32 pp.

Becker, F. H. "Judicial Evolution: The C. Edwin Moore Years." Drake Law Review 38 (1988-1989), 729-35. Late Chief Justice of the Iowa Supreme Court.

Behne, Theodore A. 150 Years, 1837-1987: The Sesquicentennial of the Police Department of Burlington, Iowa. Burlington, 1987. 68 $\mathrm{pp}$.

Brown, Bruce. Lone Tree: A True Story of Murder in America's Heartland. New York: Crown, 1989. 220 pp. The 1985 killings of a banker and others and the suicide of Dale Burr.

Case, Tony. "Court Says Paper Did Not Libel Its Competitor." Editor and Publisher 124 (23 March 1991), 24. Shenandoah Valley News and Shenandoah Evening Sentinel. 
Cumberland, William. "Walking Straight: Claud McMillan and the Anti-Saloon League." Palimpsest 69 (Winter 1988), 191-200.

Douglas, Bill. "Getting (in) Over the Wall." Christianity and Crisis 50 (5 March 1990), 54-55. Ex-prisoner describes how he was prevented from doing church ministry work by bureaucratic red tape.

Fish, Donald E. "A Stakeout for Bonnie and Clyde." Palimpsest 72 (Summer 1991), 104.

Fisher, Scott M. “Mrs. Miller's 'Boys.'" Iowan 39 (Summer 1991), 16-23. The establishment of the Iowa State Patrol in the 1930s.

Fitzgerald, Mark. "Iowa Attorney General: Police Must Tell Victims' Names." Editor and Publisher 123 (1 September 1990), 10-11.

Hines, N. William. "The Iowa Law Review: A Tradition of Excellence." Iowa Law Review 75 (May 1990), 821-27.

Irons, Peter. The Courage of Their Convictions. New York: Free Press, 1988. 420 pp. Ch. 10, "Mary Beth Tinker v. Des Moines," pp. 23152, the case of a 13-year-old Des Moines student suing for the right to wear a black armband to protest the Vietnam War.

Jordan, Philip D. "In Search of Local Legal Records." American Archivist 33 (October 1970), 379-82. Upper Mississippi River towns, includes Iowa.

Lingwall, Jill. "Gangs in Des Moines: Getting Them to SCAT." Public Management 72 (November 1990), 15-16. Strategic Complement Against Thugs.

Margolin, Frank J. History of the United States District Court for the Northern District of Iowa, 1882-1987. Sioux City, 1987. 70 pp.

Peterson, Richard W. The Court Moves West: A Study of the United States Supreme Court Decisions of Appeals from the United States Circuit and District Court of Iowa, 1846-1882. Council Bluffs: Southside Press of the Midlands, 1988. 68 pp.

"Prison Reform." Public Interest 95 (Spring 1989), 122-23.

Rasmussen, Elaine L. "Iowa Supreme Court Decisions Relating to the Implementation of Iowa Law in Public School Settings from 1971 to 1988." Ph.D. diss., lowa State University, 1989. 239 pp.

Rowan, Roy. "A Time to Kill, and a Time to Heal." Time 137 (8 April 1991), 11-12. Dreesman family murders in Algona.

Thompson, Tommy R. "Feeblemindedness, Criminal Behavior, and Women: A Turn-of-the-Century Case Study." Palimpsest 71 (Fall 1990), 132-44.

Wertsch, Douglas. "The Evolution of the Des Moines Police Department: Professionalization and the Decline of Public Disorder Arrests in the Twentieth Century." Annals of Iowa 48 (Winter/ Spring 1987), 435-49. 
. "Iowa's Daughters: The First Thirty Years of the Girls Reform School of Iowa, 1869-1899." M.A. thesis, Iowa State University, 1987. $168 \mathrm{pp}$.

. "Iowa's Daughters: The First Thirty Years of the Girls Reform School of Iowa, 1869-1899." Annals of Iowa 49 (Summer/Fall 1987), 77-100.

Wueschner, Silvano A. "The Movement for Workmen's Compensation Legislation in Iowa, 1911-1913." M.A. thesis, Northeast Missouri State University, 1987. 132 pp.

\section{Medicine AND Health CaRe}

Anderson, Lee. "A Case of Thwarted Professionalization: Pharmacy and Temperance in Late Nineteenth-Century Iowa." Annals of Iowa 50 (Winter 1991), 751-71.

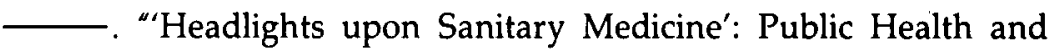
Medical Reform in Late Nineteenth-Century Iowa." Journal of the History of Medicine and Allied Sciences 46 (April 1991), 178-200.

- Iowa Pharmacy, 1880-1905: An Experiment in Professionalism. Iowa City: University of Iowa Press, 1989. $190 \mathrm{pp}$.

- "The Politics of Pharmaceutical Specialization: Iowa as a Case Study, 1875-1905." Ph.D. diss., University of Iowa, 1987. $291 \mathrm{pp}$.

Betterley, Connie, and Brenda Dobson. "Evaluation Tools for Nutrition Education Materials." Journal of Nutrition Education 22 (May-June 1990), 140B. Iowa Department of Health nutrition policy.

Bonfiglio, Michael. "Orthopaedic Pathology at the University of Iowa: Sagacity and Serendipity." Iowa Orthopaedic Journal 10 (1990), 9-13.

Burmeister, Leon F. “Cancer Mortality in Iowa Farmers, 1971-1978." Journal of the National Cancer Institute 66 (March 1981), 461-64.

Edgington, Byron. "Angels in the Sky." Iowan 38 (Spring 1990), 46-50. Air Care, an emergency helicopter service:

Fuortes, Laurence, Louise A. McNutt, and Charles Lynch. "Leukemia Incidence and Radioactivity in Drinking Water in 59 Iowa Towns." American Journal of Public Health 80 (October 1990), 1261-62.

Glass, Gina E., William J. Hausler, Paul L. Loeffelholz, and Charles E. Yesalis III. "Seroprevalence of HIV Antibody among Individ- 
uals Entering the Iowa Prison System." American Journal of Public Health 78 (April 1988), 447-49.

Iowa's Early Home Remedies. Sioux City: Quixote Press, 1990. 179 pp.

McCray, Paul B., Jr. A History of the Department of Pediatrics, University of Iowa Hospitals and Clinics, 1870-1986. Iowa City: University of Iowa, 1987. 127 pp.

Margolis, Richard J. "A Hospital for All Seasons." New Leader 71 (14 November 1988), 14-15. People's Memorial Hospital, Independence.

Massey, Robert U. "William Bennett Bean, 1909-1989: Clinical Scholar and Historian of Medicine." Journal of the History of Medicine and Allied Sciences 44 (July 1989), 285-87. University of Iowa College of Medicine professor.

Moore, Galen A., Thomas Landreth, Dean Siem, Karen Sheppard, and Jackie Hall. "Food Sanitation Enforcement: County Inspection Program Increases Compliance." Journal of Environmental Health 53 (September-October 1990), 17-18.

Morrell, David. Fireflies. New York: Dutton, 1988. 216 pp. Writer and former professor of English at University of Iowa writes about his son's death from cancer.

Naides, Stanley J. “Erythema Infectiosum (Fifth Disease) Occurrence in Iowa." American Journal of Public Health 78 (September 1988), 1230-31.

Oakland, Mary Jane, and Patrice A. Thomsen. "Beliefs about and Usage of Vitamin/Mineral Supplements by Elderly Participants of Rural Congregate Meal Programs in Central Iowa." Journal of the American Dietetic Association 90 (May 1990), 715-16.

Smit, Ann B., Linda Hand, J. Joseph Freilinger, John E. Bernthal, and Ann Bird. "The Iowa Articulation Norms Project and its Nebraska Replication." Journal of Speech and Hearing Disorders 55 (November 1990), 779-98.

Sutcliffe, John W. Memories of an Iowa Veterinarian. Santa Barbara, CA: Geronima Press, 1990.

"The William B. Bean Festschrift." Archives of Internal Medicine 134 (November 1974). Professor in University of Iowa College of Medicine, 1909-1989.

Wood, Sharon E. “'My Life Is Not Quite Useless': The 1866 Diary of an Asylum Bookkeeper." Palimpsest 70 (Spring 1989), 2-13. Iowa Hospital for the Insane, Mt. Pleasant. 


\section{POPULATION STUDIES}

Daniels, Thomas L., and Mark B. Lapping. "Small Town Triage: A Rural Settlement Policy for the American Midwest." Journal of Rural Studies 3 (1987), 273-80.

Goudy, Willis J. Population in Iowa's Townships, 1900-1980. Ames: Cooperative Extension Service, Iowa State University, 1988. 28 pp.

Goudy, Willis J., and Kimberly Van Dalen. Iowa's Population from 1910 to 1988: Births, Deaths, and Migrations. Ames: Cooperative Extension Service, Iowa State University, 1989. 4 pp.

Goudy, Willis J., and Rogelio Saenz. Iowa's Urban and Rural Population, 1880-1980. Ames: Cooperative Extension Service, Iowa State University, 1982. 2 pp.

Goudy, Willis J., and Sandra C. Burke. Iowa's Counties in 1980 and 1990: Initial Census Counts on Population, Race, Hispanic Origin, and Housing Units. Ames: Census Services, Iowa State University, $1991.6 \mathrm{pp}$.

- Iowa's Incorporated Places in 1990: Initial Census Counts on Population, Race, Hispanic Origin, and Housing Units. Ames: Census Services, Iowa State University, 1991. 22 pp.

- Iowa's Townships in 1990: Initial Census Counts on Population, Race, Hispanic Origin, and Housing Units. Ames: Census Services, Iowa State University, 1991. 28 pp.

- Population Change in Iowa's Incorporated Places, 1850 to 1986. Ames: Cooperative Extension Service, Iowa State University, 1988. 20 pp.

- Population Change in Iowa's Incorporated Places, 1970 to 1980. Ames: Cooperative Extension Service, Iowa State University, 1985. 4 pp.

- Vital Statistics and Other Population Components for Iowa Counties, 1850-1986. Ames: Cooperative Extension Service, Iowa State University, 1988. 28 pp.

- Vital Statistics and Other Population Components for Iowa Counties, 1980-1985. Ames: Cooperative Extension Service, Iowa State University, 1987. $20 \mathrm{pp}$.

Goudy, Willis J., Seung-pyo Hong, and John Wallize. Farm, Rural Nonfarm, and Urban Residents of Iowa: 1980 and Fifty Years of Perspective. Ames: Iowa State University Cooperative Extension Service, 1988. $95 \mathrm{pp}$. Includes decline in farm and increase in rural nonfarm and urban residents, with demographic characteristics, 1930-1980. 
Hudson, John C. "North American Origins of Middlewestern Frontier Populations." Annals of the Association of American Geographers 78 (September 1988), 395-413. Includes Iowa.

Webber, M. J. "Population Growth and Town Location in an Agricultural Community: Iowa, 1840-1960." Geographical Analysis 4 (April 1972), 134-55.

Westfall, John E. "The Demographic Inflection: Iowa and Nebraska." Proceedings of the Association of American Geographers 2 (1970), 149-52. Population density of frontier settlement, 1840-1960.

\section{RECREATION AND SPORTS}

\section{Sports-General}

Bender, Jack. A Gallery of Iowa Sports Heroes: Five Decades of Cartoons by Jack Bender. Cedar Rapids: Voice of the Hawkeyes, 1989. $74 \mathrm{pp}$.

Bryson, Bill. The Babe Didn't Point and Other Stories about Iowans and Sports. Ames: Iowa State University Press, 1989. 256 pp.

Carney, Clem. You've Gotta' Be Kidding: The Lighter Side of Coaching and Officiating. Iowa City: Useful Curriculum Corp., 1989. 151 pp.

Lienau, Maureen K. "Academic Success and Persistence of Intercollegiate Athletic Females." M.A. thesis, University of Iowa, 1983. $41 \mathrm{pp}$. University of Iowa, 1976-1982.

Shanley, Mary Kay. "On the Mark ... the Iowa Games." Iowan 39 (Summer 1991), 8-15.

\section{Basketball}

Cook, Kevin. "The Iowa Girl Stands Tall." Sports Illustrated 70 (13 February 1989), 76-85.

Davis, Tom. "Iowa's Zone Offense." Scholastic Coach 57 (November 1987), 22-25.

Erickson, Lori. "Her Coaching Is Tops!" Iowan 36 (Spring 1988), 18-21. University of Iowa women's coach C. Vivian Stringer.

Garrity, John. "The Unknown Cyclone." Sports Illustrated 67 (21 December 1987), 86. Jeff Grayer of Iowa State University.

Jennings, Jay. "Winning Votes in lowa." Sports Illustrated 68 (15 February 1988), 156. University of Iowa women's coach C. Vivian Stringer. 
Kirkpatrick, Curry. "A Ferocious Game of Family Feud." Sports Illustrated 66 (9 February 1987), 74-78. Big Ten basketball.

Miller, Ralph. Spanning the Game. Champaign, IL: Sagamore Publishing, 1990. 222 pp. Part 3, "Coaching at Iowa," pp. 77-110.

Wolff, Alexander. "Las Vegas Hit the Jackpot." Sports Illustrated 66 (30 March 1987), 22-23. NCAA Final Four.

\section{Wrestling}

Chapman, Mike. Frank Gotch: World's Greatest Wrestler. Buffalo, NY: Hein and Co., 1990. 139 pp.

- Nick and the Cyclones. Champaign, IL: Leisure Press, 1988. 141 pp. Harold Nichols, Iowa State University wrestling coach, 1953-1985.

Iowa State Wrestling, 1990-91: 75 Years. Ames: Iowa State University, 1990. 59 pp.

Lieber, Jill. "A Cactus Supplants Corn." Sports Illustrated 68 (28 March 1988), 58-59. NCAA wrestling, Arizona State over Iowa.

Looney, Douglas S. "Stopped Short of the Magic X." Sports Illustrated 66 (30 March 1987), 36-37. NCAA wrestling, Iowa State stops Iowa.

Murphy, Austin. "Grand Grapple in the Midwest." Sports Illustrated 66 (2 March 1987), 20-21. Iowa over Iowa State.

Neff, Craig. "Swept Up by a Cyclone: Arizona State, the Surprise No. 1, Fell to Iowa State." Sports Illustrated 68 (18 January 1988), 81-82.

Noden, Merrell. "Real Fire Brands: Iowa Won the NCAA Title with the Help of the Cantankerous Brands Brothers." Sports Illustrated 74 (25 March 1991), 62-63. Tom and Terry Brands.

Raab, Scott. "Nasty Dan and His Wrestling Empire." Sport 79 (April 1988), 38-45. Dan Gable.

\section{Football}

Ballard, Sarah. "Some Vintage Advertising." Sports Illustrated 67 (12 October 1987), 18. Bartles \& James ads parodied by Iowa State coaches.

Couppee, Al. One Magic Year, 1939: An Ironman Remembers. 1989. $145 \mathrm{pp}$.

Fisher, Scott M. The Ironmen: The 1939 Hawkeyes. Lincoln, NE: Media Publishing, 1989. 128 pp.

Garrity, John. "From Surfer to Cyclone: Southern California Native Blaise Bryant Is Now, Improbably, Tearing Up Corn Country 
for Iowa State." Sports Illustrated 73 (3 September 1990), 76-78.

- "Marv Cook." Sports Illustrated 69 (5 September. 1985), 90. University of Iowa tight end/punter.

Harker, Carol. "100 Years of Iowa Football." Part 1, "Gridiron Glory: 1889-1939," Iowa Alumni Review 42 (September 1989), 16-33; Part 2, "Football Fever: 1940-1989," ibid: (November 1989), $16-31$.

Hooley; Bruce. “Holiday Bowl: No. 9 Iowa vs. No. 23 BYU." Sporting News 212 (23 December 1991), S9.

Looney, Douglas S. "Bell of the Ball." Sports Illustrated 73 (12 November 1990), 20-21. Nick Bell and the Iowa-Illinois game.

- "Dashing Debut by the Vols." Sports Illustrated 67 (7 September 1987), 22-23. Tennessee-Iowa game.

McCarney, Dan. "Iowa's Slant Defense Techniques." Scholastic Coach 57 (September 1987), 26-29.

Murphy, Austin. "The Rose Woes." Sports Illustrated 73 (3 December 1990), 88-89. Iowa goes to the Rose Bowl.

Oberlander, Susan. "Iowa State U. Honors Its First Black Athlete, Ending Long Controversy." Chronicle of Higher Education 34 (22 June 1988), A29-A30. Jack Trice.

One Hundred Years of lowa Football, 1889-1989. Vol. 1, Seventy-Five Years with the Fighting Hawkeyes, by Dick Lamb and Bert McGrane. 284 pp. Vol. 2, Twenty-five Years with the Fighting Hawkeyes: Fourth Quarter, 1964-1988, by Al Grady. 196 pp. Iowa City: University of Iowa, 1989. Volume 1 is a reprint of 1964 ed.

Reed, William F. "Playing Through the Pain." Sports Illustrated 75 (11 November 1991), 146. Iowa's 16-9 win over Ohio State.

Steward, Roger: Cyclone Memories: 100 Years of Iowa State Football. Webster City: S \& RS Publishers, 1991. 310 pp.

Wulf, Steve. "Frosh Fracas." Sports Illustrated 70 (24 April 1989), 13-14. Eligibility rules at the University of Iowa.

\section{Gambling}

Baker, James N. "Gambling on Riverboats: War Between the States." Newsweek 115 (5 February 1990), 22.

Ballen, Kate. "Riverboat Gambling Is Back." Fortune 123 (22 April 1991), 14.

"Floating Crap Games." Time 137 (15.April 1991), 39. Riverboat casinos. 
Hume, Scott. "River Gambling Rolls in Iowa." Advertising Age 62 (8 April 1991), 17.

Siler, Charles. "Why Are Las Vegas and Atlantic City Yawning?" Forbes 145 (30 April 1990), 140. Riverboat casinos.

\section{Hiking and Bicycling}

Blackman, Paddy, and Jennifer Figge. Running Home: An AcrossIowa Journal. Eldridge, 1989. 126 pp.

Hedberg, Nancy A. "This Trail's Right on Track!" Iowan 38 (Fall 1989), 10-15, 56. Cedar Valley Nature Trail.

Leerhsen, Charles. "Pedaling to the Next Century." Newsweek 116 (23 July 1990), 60. Includes RAGBRAI.

Little, Charles E. Greenways for America. Baltimore: Johns Hopkins University Press, 1990. 237 pp. Includes the Heritage Trail, Dubuque County, pp. 43-48.

McGrath, Susan. "They've Been Walking on the Railroad." National Wildlife 26 (August-September 1988), 40-43. Cedar Valley Nature Trail.

Shanley, Mary Kay. "Folks and Spokes." Women's Sports and Fitness 13 (March 1991), 52-57. Des Moines Register's RAGBRAI.

\section{Water Sports and Recreation}

Erickson, Lori. "They're Wild about Woodies!" Iowan 38 (Summer 1990), 18-23, 64. Vintage wooden boats at shows sponsored by the Antique and Classic Boat Society.

Hakes, Richard. "New Lady on the Lake." Iowan 35 (Spring 1987), 46-50. The Queen II, Lake Okoboji.

Harlan, James R., and Everett B. Speaker, with James Mayhew. Iowa Fish and Fishing. 5th ed. Des Moines: Iowa Dept. of Natural Resources, 1987. 327 pp.

Lawrence, Bob. "What's Going On at lowa's Great Lakes?" Iowan 38 (Summer 1990), 10-17, 44-45.

Waller, Robert. "A Ride on the River." Iowan 38 (Summer 1990), 66, 64-65. "The Spirit of Greene" on the Shell Rock River.

Whye, Mike. "It's MADRAC, not Mad Race!" Iowan 37 (Summer 1989), 10-14, 46-49. Annual canoe trip on the Mississippi River.

The Des Moines Rowing Regatta. 


\section{Other Sports and Recreation}

Aegerter, Roger. Golf Courses of Iowa: A Complete Book of Iowa Golf Courses. Jefferson, 1988. 224 pp.

Henderson, Joe. "Runs in the Family." Runner's World 24 (August 1989), 14. Drake Relays.

Putnam, Pat. "Nunn Better." Sports Illustrated 70 (22 May 1989), 40-45. Biographical sketch of Michael Nunn of Davenport, International Boxing Federation middleweight champion.

Sanders, Jeff. "Can of Corn." American Film 14 (September 1989), 15. Baseball diamond from motion picture, "Field of Dreams," Dyersville.

Shanley, Mary Kay. "He's the Voice of the Drake Relays." Iowan 37 (Spring 1989), 42-49. Jim Duncan.

Springen, Karen. "The Monaco of the Midwest: Grand Prix Racing Brings Heartthrobs and Hassles." Newsweek 110 (13 July 1987), 42.

Whye, Mike. "Hunters of the Sky." Iowan 37 (Winter 1988), 56-60. Falconry.

- . "Knoxville: Where Sprint Cars Rule the Road." Iowan 35 (Summer 1987), 52-61.

- "Rodeo!" Iowan 37 (Summer 1989), 30-37, 60-61. Fort Madison's Tri-State Rodeo.

- "There's Drama up in the Air!" Iowan 38 (Summer 1990), 46-51, 59-60. Ida Grove's Aviation Expo.

-. . "When There's Snow, All Trails Lead to Cresco." Iowan 40 (Winter 1991), 50-53, 59, 63. Snowfest snowmobile rally.

Woodring, Jeannie. "See How Their Gardens Grow!" Iowan 38 (Spring 1990), 33-39. Des Moines gardeners.

\section{Parks and Preserves}

Boge, Michael A. Union Park, A Place of Memories. Dubuque, 1983. $118 \mathrm{pp}$.

Felton, Debbie. "A Zoo Grows Up." Iowan 35 (Spring 1987), 8-12, 42-43. Blank Park Zoo, Des Moines.

Garmon, Netalie. "Magic in the Park." Iowan 35 (Spring 1987), 59-62. Redhead Park, Des Moines.

Haskell, Jonan. Our Park at the Top of the Hill; Or the History of North Hill Park, North Hill, Burlington, Des Moines County, Iowa. Burlington, 1989. 243 pp. 
"It's History Afloat." Iowan 37 (Spring 1989), 54-61. Volunteers build a replica of a keelboat at Lewis and Clark State Park near Onawa.

Quinn, Christine A., Robert J. Naisbitt, and Mark E. Stegmaier. "Butterfly Garden." Iowan 36 (Summer 1988), 22-25, 39. Bellevue State Park.

Wolf, Robert C. Iowa's State Parks: Also Forests, Recreation Areas, and Preserves. Ames: Iowa State University Press, 1991. 224 pp.

\section{RELIGION}

\section{General}

Balmer, Randall. Mine Eyes Have Seen the Glory: A Journey into the Evangelical Subculture in America. New York: Oxford University Press, 1989. 246 pp. Includes Donald W. Thompson, a Christian filmmaker from Des Moines, and evangelical Christian activism in the 1988 Iowa presidential caucuses.

\section{Christian Church (Disciples of Christ)}

Andrews, Mrs. E. J. History of Milton Christian Church, Milton, Iowa. Rev. ed. 1987. 16 pp.

\section{Church of God}

Burnett, Francis, ed. History of the Iowa Church of God and Conference: "These People Called Restitutionists," 1855-1987. Waterloo, 1987. 65 pp.

\section{Church of Jesus Christ of Latter-day Saints (Mormons)}

Bennett, Richard Edmond. Mormons at the Missouri, 1846-1852: "And Should We Die...." Norman: University of Oklahoma Press, 1987. 347 pp. Originally a Ph.D. diss., Wayne State University, 1984, titled "Mormons at the Missouri: A History of the Latter-Day Saints at Winter Quarters and at Kanesville, 18461852."

Enders, Donald L. "The Steamboat Maid of Iowa: Mormon Mistress of the Mississippi." Brigham Young University Studies 19 (Spring 1979), 321-35. Boat built at Augusta, Iowa; later purchased, then sold, by Mormons.

Jennings, Warren A., ed. "Two Iowa Postmasters View Nauvoo: Anti-Mormon Letters to the Governor of Missouri." Brigham 
Young University Studies 11 (Spring 1971), 275-92. Keokuk and Montrose.

Kelly, Charles, ed. Journals of John D. Lee: 1846-47 and 1859. 1938. Reprint. Salt Lake City: University of Utah Press, 1984. 244 pp.

Zohrer, Wendy J. "The Mormon Trek across Iowa." Iowa Conservationist 49 (February 1990), 26-31.

\section{Greek Orthodox}

St. Demetrios Greek Orthodox Church, Waterloo, Iowa: 75th Anniversary Diamond Jubilee, 1914-1989. Waterloo, 1989. 189 pp.

\section{Jews}

Bell, Michael J. "To Light Out for the Territories Ahead of the Rest." Palimpsest 71 (Winter 1990), 146-53. Jewish life and heritage.

\section{Lutherans}

The Alden St. Paul's Story, Missouri Synod: The Seventy-Five Year History of St. Paul's Lutheran Church, Alden, Iowa, 1908-1983. Alden, 1983. $21 \mathrm{pp}$.

Balmer, Randall. "Washington Prairie Lutheran Church, Decorah, Iowa." Christian Century 108 (30 October 1991), 996-1000.

Bostelmann, Albert T. "Life and Ministry of Johann Wolter." Concordia Historical Institute Quarterly 61 (1988), 61-73.

First Lutheran Church, Kingsley, Iowa, 1936-1986. 1986.

Nerdig, Berdean, Dorothy Climer, and Janet Hicks. St. Luke Lutheran [Nora Springs], 1890-1990: Remembering Our Roots, Celebrating Our Fellowship from Generation to Generation. Nora Springs, 1990. 36 pp.

Nichol, Todd. "Wilhelm Lohe, the Iowa Synod and the Ordained Ministry." Lutheran Quarterly 4 (1990), 11-29.

Schmutterer, Gerhard M. Tomahawk and Cross: Lutheran Missionaries among the Northern Plains Tribes, 1858-1866. Sioux Falls, SD: Center for Western Studies, Augustana College, 1989. 219 pp. Iowa Synod mission efforts.

\section{Mennonites and the Amish}

Dow, J. R. "Toward an Understanding of Some Subtle Stresses on Language Maintenance among the Old Order Amish of Iowa." International Journal of the Sociology of Language, no. 69 (1988), 19-31. 
Graber, William B. "An Amish Mennonite Farmer Chooses Iowa." Palimpsest 69 (Winter 1988), 154-62. Daniel Conrad in 1849.

Hershberger, Alma T. Amish Life through a Child's Eyes: A Unique Experience in Amish Life. New York: Vantage Press, 1987. 150 pp.

Nisly, Hope. "A Mennonite Woman in 'Thanksgiving Town': Edith Swartzendruber Nisly's Work Experience, 1935-1941." Labor's Heritage 3 (1991), 26-33, 48. Mennonite community in southeastern Iowa.

Reschly, Steven D. “From Amisch Mennoniten to Amish Mennonites: A Clarion Call in Wright County, Iowa, 1892-1910." M.A. thesis, University of Northern Iowa, 1987. $186 \mathrm{pp}$.

Yoder, Paton. Tradition and Transition: Amish Mennonites and Old Order Amish, 1800-1900. Scottdale, PA: Herald Press. 1991. 359 pp.

Yoder, Rhonda L. "Amish Agriculture in Iowa: A Preliminary Investigation." M.A. thesis, Iowa State University, 1990. 121 pp. Old Order Amish, especially in Buchanan County.

Amish Agriculture in Iowa: Indigenous Knowledge for Sustainable Small-Farm Systems. Studies in Technology and Social Change Series, 15. Ames: Technology and Social Change Program in collaboration with Leiden Ethnosystems and Development Programme (LEAD), Institute of Cultural and Social Studies, University of Leiden, 1990. $69 \mathrm{pp}$.

Zielinski, John. The Amish Across America. 1975. Reprint. Dubuque: Kendall-Hunt, 1988. 136 pp.

- . Amish Barns Across America. Iowa City: Amish Heritage Publications, 1988. $143 \mathrm{pp}$.

- Amish Children Across America. Iowa City: Amish Heritage Publications, 1987. 48 pp.

- Amish Horsefarming Across America. Iowa City: Amish Heritage Publications, 1988. $48 \mathrm{pp}$.

\section{Methodists}

First United Methodist, Ida Grove, Iowa, 1889-1989. Ida Grove, 1989. $31 \mathrm{pp}$.

A History of the United Methodist Church of Martelle. Martelle, 1974. $35 \mathrm{pp}$.

Johnston, Lyle. The Dubuque District-A History: The United Methodist Church. Schaller: Great Plains Emporium, 1979. 128 pp.

- The Mason City District-A History: The United Methodist Church. Schaller: Great Plains Emporium, 1984. 109 pp. 
Kreiger, Irene. The United Methodist Church, Morning Sun, Iowa: Parsonage Centennial Year Historical Booklet, 1890-1990. Morning Sun, 1990.

Miller, Henry A. "Methodist Revival Meeting: Remembering a Boyhood Experience in 1865." Palimpsest 71 (Spring 1990), 12-15. Unionville.

Smith, Esther B., and Mabel S. Cavaiani. Volga United Methodist: Memoirs and Morsels, Volga, Iowa, 1849-1989. Sumner, 1989. $110 \mathrm{pp}$.

\section{Presbyterians}

Eden Presbyterian Church, 1887-1987, Rudd, Iowa. 1987. 20 pp.

This and That, Now and Then: History of Center Ridge Presbyterian Church. Center Ridge, 1988. 175 pp.

\section{Roman Catholics}

Carrico, Sister Augusta, OSF, as told to Mathias Martin Hoffman. Franciscans Under Fire: Twenty Nuns, a Girl, and a Dog; The Story of the Sisters of Saint Francis of the Immaculate Conception of the Blessed Virgin Mary, Mount St. Clare, Clinton, Iowa, 18641907. Edited by Duane Hutchinson. Lincoln, NE: Foundation Books, 1990. 190 pp.

Celebrating Our Christian Heritage: 125th Anniversary, 1859-1984, Saint Francis Xavier Parish, [Dyersville]. Dyersville, 1984.56 pp.

Coogan, M. Jane. "Clement Smyth, OSCO: Trappist Monk and Frontier Prelate." Records of the American Catholic Historical Society of Philadelphia 100 (1989): 17-37. Irish Trappist monk, immigrated to Dubuque.

Eulberg, Mary T. The Rt. Rev. Mathias M. Hoffman, V.F., Whose World Was Others. Dubuque: Witness Pub., 1989. 291 pp.

Gallagher, Mary Kevin, ed. Seed/Harvest: A History of the Archdiocese of Dubuque. Dubuque: Archdiocese of Dubuque Press, 1987. $181 \mathrm{pp}$.

Hayes, Jean K. The Merging Years: A History of St. Peter Parish, [Keokuk], 1832-1982. Keokuk, 1982. 109 pp.

Hogendorn, Bertilla D., ed. Holbrook, Saint Michael's Church, 18431956. Holbrook, 1956. $45 \mathrm{pp}$.

Hussmann, Benedict J. "Voices from the Cloister: Oral Perspectives on the Recent History of New Melleray Abbey." M.A. thesis, University of Northern Iowa, 1989. $155 \mathrm{pp}$. 
Hutchinson, Duane. Grotto Father: Artist-Priest of the West Bend Grotto. Lincoln, NE: Foundation Books, 1989. 42 pp. Paul Mathias Dobberstein.

Ortner, Roy C. Barclay Reviewed. Schiller Park, 1974. 600 pp. History of St. Francis parish and church, Barclay Township, Black Hawk County.

Paddock, Elizabeth. "The National Catholic Rural Life Conference (NCRLC)." In U.S. Agricultural Groups: Institutional Profiles, edited by William P. Browne and Allan J. Cigler, 145-47. Westport, CT: Greenwood Press, 1990.

Sacred Heart Parish, Fillmore, Iowa: Centennial, 1890-1990. Fillmore, 1990.

St. Anthony's 150th Anniversary: 1837-1987. Davenport, 1987. 144 pp.

St. Joseph's Church, Earlville, Iowa, 1887-1987. 1987.

St. Malachy's Church of Ardon, Iowa, 1988. Audubon: Jumbo Jack's Cookbook Co., 1988. 304 pp. Includes cookbook, church history, and town history.

Sallen, David, and Sheila Sallen. The History and Description of the Beautiful Stained Glass Windows in the Church of St. Mary of the Assumption, Fort Madison, lowa. Fort Madison: Rosehill Press, 1988. $19 \mathrm{pp}$.

\section{Society of Friends (Quakers)}

Hamm, Thomas D. "Joel Bean and the Revival in Iowa." Quaker History 76 (1987), 33-49.

\section{Unitarians and Universalists}

Horne, Roger. "The Christian Socialism of Thomas V. Woodrow: 'Oklahoma's First Preacher.'" Chronicles of Oklahoma 69 (1991), 78-91.

Oelberg, Sarah W. "Fire Across the Prairie: A History of Unitarianism in lowa from 1875-1910." D.Min. thesis, Meadville/ Lombard Theological School, 1991.

Tucker, Cynthia G. Prophetic Sisterhood: Liberal Women Ministers of the Frontier, 1880-1930. Boston: Beacon Press, 1990. 298 pp. Includes Iowa Unitarians.

\section{United Church of Christ}

History of the First Congregational Church (UCC) of Whiting, Iowa. 1988. $40 \mathrm{pp}$. 
Over Eighty-Five Years Together: Immanuel Memorial U.C.C., Alden, Peace U.C.C., Buckeye. Alden, 1979. 45 pp.

\section{SCIENCE}

\section{Astronomy and Physics}

Harker, Carol. "Will His Comet Theory Hold Water?" Iowan 37 (Spring 1989), 18-20, 65-66. Dr. Louis Frank, University of Iowa physics professor.

Hecht, Jeff. "Meteor in the Midwest Blamed for Extinctions." New Scientist 119 (8 September 1988), 38.

Joyce, Christopher. "Fragmentary Theory of Dinosaur Extinctions." New Scientist 117 (11 February 1988), 27. Comet showers and remains of a crater near Manson.

Monastersky, Richard. "Point of Impact: Manson, Iowa?" Science News 132 (19 December 1987), 396. Meteor that may be related to dinosaur extinction.

Needell, Allan A. "Preparing for the Space Age: University-Based Research, 1946-1957." Historical Studies in the Physical and Biological Sciences 18 (1987), 89-109. On James Van Allen at the University of Iowa.

\section{Biology}

"America's Historic Forest Takes Root." American Forests 97 JulyAugust 1991), 11-12. Dale Maffit Reservoir, Des Moines.

Baker, Debby Zieglowsky. "Eighty Years of Research at Iowa Lakeside Laboratory: A Bibliography." Journal of the Iowa Academy of Science 97 (December 1990), 190-99.

Bonta, Marcia M. “Althea Rosina Sherman, Ornithologist of an Iowa Dooryard." In Women in the Field: America's Pioneering Women Naturalists, 197-211. College Station: Texas A \& M University Press, 1991. 299 pp.

Bryan, Georgia G., and Louis B. Best. "Bird Abundance and Species Richness in Grassed Waterways in Iowa Rowcrop Fields." American Midland Naturalist 126 (July 1991), 90-102.

Christiansen, James L., and Reeve M. Bailey. The Lizards and Turtles of Iowa. Des Moines: Iowa Dept. of Natural Resources, 1988. 19 $\mathrm{pp}$.

Dinsmore, James, et al. Iowa Birds. Ames: Iowa State University Press, 1984. 354 pp. 
Erickson, Lori. "A Prairie Takes 'Root." Iowan 39 (Summer 1991), 74, 72-73. Native flowers and grasses planted by a Decorah couple.

Goldstein, Daniel. "Midwestern Naturalists: Academies of Science in the Mississippi Valley, 1850-1900." Ph.D. diss., Yale University, 1989. 356 pp. Davenport Academy of Natural Sciences (later the Putnam Museum) and three other academies.

Graham, Frank, Jr. "Prairie Colors." Audubon 93 (March 1991), 20-21. Growing native plants.

Kinseth, Lance. River Eternal: The Wonder of Common and Ashen Days Alongside a Prairie River. New York: Viking, 1989. 154 pp. Des Moines writer describes natural world around the "Moingona" River.

Madson, John. "Christmas Is a Land of Promise." National Wildlife 25 (December 1986-January 1987), 22-28. Prairie natural history.

- Stories from under the Sky. Ames: Iowa State University Press, 1988. 206 pp. Naturalist writes 36 short accounts.

Musgrove, Jack, and Mary Musgrove. Waterfowl in Iowa. 5th ed. Des Moines: State Conservation Commission, 1977. 130 pp.

Olson, Jean E., with assistance from Donald R. Lewis, et al. Landscape Plants for Iowa. Rev. ed. Ames: Cooperative Extension Service, Iowa State University, 1984. $111 \mathrm{pp}$.

Patterson, Rich, and Marion Patterson. "T.R.E.E.S. Forever." American Forests 96 (September-October 1990), 54-57. Organization that promotes tree planting.

Petersen, Peter C., ed. Birding Areas of Iowa. Monticello: Iowa Ornithologists' Union, 1979. $153 \mathrm{pp}$.

Quinn, Christine A., and Robert J. Naisbitt. "An Iowa Home for Canada Geese." Iowan 38 (Winter 1989), 52-55. Bob Swartz of Dallas County.

Runkel, Sylvan T., and Alvin F. Bull. Wildflowers of Iowa Woodlands. 1979. Reprint. Ames: Iowa State University Press, 1987. 272 pp.

Runkel, Sylvan T., and Dean M. Roosa. Wildflowers of the Tallgrass Prairie: The Upper Midwest. Ames: Iowa State University Press, 1989. $279 \mathrm{pp}$.

Staw, Jane A., and Mary Swander. Parsnips in the Snow: Talks with Midwestern Gardeners. Iowa City: University of Iowa Press, 1990. 223 pp.

Van Der Linden, Peter J., and Donald R. Farrar. Forest and Shade Trees of Iowa. Ames: Iowa State University Press, 1984. 134 pp. 
Wood, Sharon E. "Althea Sherman and the Birds of Prairie and Dooryard: A Scientist's Witness to Change." Palimpsest 70 (Winter 1989), 164-85.

\section{Conservation and Environmental Concerns}

Brownlee, Shannon. "Brave New Breadbasket." U.S. News and World Report 108 (23 April 1990), 64. Iowa Department of Natural Resources survey of groundwater contamination.

Canine, Craig. "The Second Coming of Energy Conservation." Utne Reader no. 37 (January-February 1990), 114-21. Osage.

Gillette, Lynne M. "Indoor Radon in Iowa Homes." M.S. thesis, Iowa State University, 1988. $69 \mathrm{pp}$.

Hallberg, G. R., et al. Groundwater Monitoring in the Big Spring Basin, 1984-1987: A Summary Review. Geological Survey Technical Information series, no. 16. Iowa City: Iowa Dept. of Natural Resources, 1989. $68 \mathrm{pp}$.

Howard, Beth. “Our Town." Omni 13 (May 1991), 12. Energy conservation in Osage.

J. N. "Ding" Darling's Conservation and Wildlife Cartoons. Des Moines: J. N. "Ding" Darling Foundation, 1991. 51 pp:

Kersten, Herbert H. A Brief History of Iowa with a Proposal for Our Future. Fort Dodge, 1987. 44 pp. History and ideas for a prairie park.

Lemonick, Michael D. "Feeling the Heat: The ProblemGreenhouse Gases Could Create a Climatic Calamity." Time 133 (2 January 1989), 36-39. Includes energy conservation in Osage.

Lovell, Jan. "She Fought to Save Iowa's Prairies." Iowan 36 (Winter 1987), 22-27, 56-57. Educator Ada Hayden's conservation efforts.

Nichols, Keith. "The Case of Cottonwood Mile." Sierra 75 (November-December 1990), 21. A stand of trees lost in order to widen a road.

Rohde, Dan. "He's a Guardian of the Endangered." Iowan 37 (Summer 1989), 52-55. James Christiansen.

Solecki, William D. "Acute Chemical Disasters and Rural United States Hazardscapes." Ph.D. diss., Rutgers University, 1990. Covers Alabama, Georgia, Iowa, and New York, 1982-1989.

Whye, Mike. "She's Putting Life Back into the Wild." Iowan 36 (Fall 1987), 44-49. Linda Hinshaw, Spirit Lake, takes care of orphaned and injured animals.

Zimmerman, Bob. Jones Creek Watershed: A Pioneer. Onawa: Monona County Soil Conservation District, 1978. 11 pp. Soil Conserva- 
tion Service demonstration project built by CCC, Monona County, 1937-1978.

\section{Geology, Hydrology, and Paleontology}

Anderson, Wayne, and Rick Stinchfield. "Pint's Quarry, Black Hawk County, Iowa." Mineralogical Record 20 (November-December 1989), 473-79.

Baker, R. G., D. P. Schwert, E. A. Bettis III, T. J. Kemmis, D.C. Horton, and H. A. Semken. "Mid-Wisconsinian Stratigraphy and Paleoenvironments at the St. Charles Site in South-central Iowa." Bulletin of the Geological Society of America 103 (February 1991), 210-20.

Bolt, John R., R. M. McKay, B. J. Witzke, and M. P. McAdams. “A New Lower Carboniferous Tetrapod Locality in Iowa." Nature 333 (23 June 1988), 768-70.

Chumbley, C. A., R. G. Baker, and E. A. Bettis III. "Midwest Holocene Paleoenvironments Revealed by Floodplain Deposits in Northeastern Iowa." Science 249 (20 July 1990), 272-74. Vegetational changes during the past 12,500 years revealed by pollen analysis.

Hokanson, Drake. "The Prairie Is Their Classroom." Iowan 36 (Spring 1988), 34-39, 60-62. Loess Hills Prairie Seminar.

Kunk, M. J., G. A. Izett, R. A. Haugerud, and J. F. Sutter. "Argon40-Argon-39 Dating of the Manson Impact Structure: A Cretaceous-Tertiary Boundary Crater Candidate." Science 244 (30 June 1989), 1565-68.

Monastersky, Richard. "Ancient Amphibians Found in Iowa." Science News 133 (25 June 1988), 406.

Mutel, Cornelia F. Fragile Giants: A Natural History of the Loess Hills. Iowa City: University of Iowa Press, 1989. 284 pp.

O'Connor, Colleen. 'Is There Oil in Iowa? The Rig Behind a Hog Barn May Tell the Tale." Newsweek 109 (22 June 1987), 26. Amoco Oil Co. explorations in Halbur.

Panchen, Alec L. "In Search of Earliest Tetrapods." Nature 333 (23 June 1988), 704.

Prior, Jean C. Landforms of Iowa. Iowa City: University of Iowa Press for the Iowa Department of Natural Resources, 1991. 153 pp.

- "Loess Hills: A National Natural Landmark." Iowa Science Teachers Journal 25 (Winter 1988-89), 17-21. Reprinted from 1987 issue of lowa Geology.

"Rise of the Tetrapods." Discover 9 (October 1988), 14. 
Rogers, Frederick S. “Stratigraphy, Depositional History, and Conodonts of the Little Cedar and Lower Coralville Formations of the Cedar Valley Group (Middle Devonian) of Iowa." Ph.D. diss., University of Iowa, 1990.

Schwert, D. P., and A. C. Ashworth. "Ice Age Beetles." Natural History (January 1990), 10.

Siegel, D. I. "Evidence for Dilution of Deep, Confined Water by Vertical Recharge of Isotopically Heavy Pleistocene Water." Geology 19 (May 1991), 433-36. Des Moines geology.

Van Schmus, W. R., M. E. Bickford, R. R. Anderson, C. K. Shearer, J. J. Papike, and B. K. Nelson. "Quimby, Iowa, Scientific Drill Hole: Definition of Precambrian Crustal Features in Northwestern Iowa." Geology 17 (June 1989), 536-39.

Witzke, Brian J. "Geodes: A Look at Iowa's State Rock." Iowa Science Teachers Journal 26 (Spring 1989), 22-24.

—. "Geodes from Iowa." Earth Science 41 (Summer 1988), 19.

\section{Meteorology}

Jenison, Norma Jeanne, and Starr Jenison Benjamin. The "Eyes" of the Storm: Belmond, Iowa, Recalls the 1966 Homecoming Day Tornado. St. Paul, MN: L. Lydia Press, 1989. 214 pp.

Tornado Hits Council Bluffs, Iowa: Black Friday, July 15, 1988, 4:14 p.m.: A Diary of Destruction. Sun City West, AZ: C. F. Boone, 1988. 64 pp.

Stanford, John L. Tornado: Accounts of Tornadoes in Iowa. $2 \mathrm{~d}$ ed. Ames: Iowa State University Press, 1987. 154 pp.

\section{Technology and Invention}

Burks, Alice R., and Arthur W. Burks. The First Electronic Computer: The Atanasoff Story. Ann Arbor: University of Michigan Press, 1988. $387 \mathrm{pp}$.

Mollenhoff, Clark R. Atanasoff: Forgotten Father of the Computer. Ames: Iowa State University Press, 1988. 274 pp.

Reichel, Brian J. "Exploring the University-Industry-Government High Technology Research Triad: Public Policy Ramifications of Biotechnology." Ph.D. diss., Iowa State University, 1990. 226 pp.

Wolfe, Tom. "The Tinkerings of Robert Noyce." Esquire (December 1983), 346-74. Iowan who attended Grinnell College and later helped develop the microchip. 


\section{Social CONDITIONS AND PROBLEMS}

\section{Abolitionism}

Acton, Richard. "The Story of Ann Raley: Mother of the Coppoc Boys." Palimpsest 72 (Spring 1991), 20-33. Quaker abolitionist from Springdale whose sons accompanied John Brown.

Lucas, Thomas A. "Men Were Too Fiery for Much Talk: The Grinnell Anti-Abolitionist Riot of 1860." Palimpsest 68 (Spring 1987), 12-21.

\section{Nativism}

Eckelberg, M. E. "The American Protective Association Connection and the Reverend Frederic Cyrille Jean." Social Justice Review 74 (May-June 1983), 84-94; (July-August 1983), 119-25; (September-October 1983), 153-59; (November-December 1983), 176-82; 75 (January-February 1984), 18-30; (MarchApril 1984), 51-58; (May-June 1984), 84-93; (July-August 1984), 108, 117-25; (September-October 1984), 143-55; 76 (January-February 1985), 23-29. Involvement of the nativist organization in the murder of a Catholic priest.

\section{Race Relations and Civil Rights}

Celebration of Civil Rights: An Iowa Tradition 1965-1990. Des Moines: Iowa Civil Rights Commission, 1990. 31 pp.

Christian, Rebecca. "Nun's 6th-Graders Counter Violence on Blacks in Dubuque." National Catholic Reporter 28 (20 December 1991), 3. Sister Mary Lee Cox.

Findlay, James F. "Religion and Politics in the Sixties: The Churches and the Civil Rights Act of 1964." Journal of American History 77 (June 1990); 66-92. Much on Iowa support of the bill, in letters and petitions sent to senators James Bromwell and Bourke Hickenlooper.

Hewitt, William L. "Blackface in the White Mind: Racial Stereotypes in Sioux City, Iowa, 1874-1910." Palimpsest 71 (Summer 1990), 68-79.

Hull, John D. "A White Person's Town?" Time 138 (23 December 1991), 39-40. Dubuque.

Mehler, Barry. "Ralph Scott's Curious Career: Rightist on the Rights Panel." Nation 246 (7 May 1988), 640-42. UNI professor of educational psychology on the Iowa Advisory Commission on Civil Rights. 
Stone, Robert Benjamin. "The Legislative Struggle for Civil Rights in Iowa, 1947-1965." M.A. thesis, Iowa State University, 1990. $130 \mathrm{pp}$.

\section{Gender-Related Issues}

Hewitt, William L. "Wicked Traffic in Girls: Prostitution and Reform in Sioux City, 1885-1910." Annals of Iowa 51 (Fall 1991), 12348.

Hoffman, Pam. "Pro-life Editor, Reporter Sue Former Employer." Editor and Publisher 124 (9 March 1991), 37, 39. John Kennedy and Terri Lambertsen vs. Fairfield Daily Ledger.

Kantrowitz, Barbara, and Heather Woodin. "Diagnosis: Harassment: A Medical-School Prof Overcomes Sexual Slurs." Newsweek 116 (26 November 1990), 62. Jean Jew's sexual harassment case against the University of Iowa.

Mohr, James C. "Iowa's Abortion Battles of the Late 1960s and Early 1970s: Long-term Perspectives and Short-term Analyses." Annals of Iowa 50 (Summer 1989), 63-89.

Saunders, Edward. "Neonaticides Following 'Secret' Pregnancies: Seven Case Reports." Public Health Reports 104 (July-August 1989), 365-72.

\section{Children and Youth}

Blackman, James A. Screening Children at Risk: The Iowa Experience. Iowa City: Division of Developmental Disabilities, University Hospital School, [1987].

McOllough, Verlene. "The Orphan Train Comes to Clarion." Palimpsest 69 (Fall 1988), 144-50.

Saunders, Edward J. "Residential Program Services Pregnant Teens and Young Mothers in Iowa." Children Today 19 (JanuaryFebruary 1990), 8-12. Adolescent Pregnancy Program of Central Iowa.

Walker, James R. "How Viewing of MTV Relates to Exposure to Other Media Violence." Journalism Quarterly 64 (Winter 1987), 756-62. Iowa youth.

\section{Aging}

Alter, Catherine F. "The Changing Structure of Elderly Service Delivery Systems." Gerontologist 28 (February 1988), 91-98.

"Good Morning! Are You OK?" Time 133 (1 May 1989), 59. Telephone system in Osage to check on senior citizens. 


\section{Temperance, Prohibition, and Alcohol Use}

Mulford, Harold A., and J. L. Fitzgerald. "Per-capita Alcohol Sales, Heavy Drinker Prevalence, and Alcohol Problems in Iowa for 1958-1985." British Journal of Addiction 83 (1988), 265-68.

\section{Social Services}

Black, Donald W. "The Iowa Record-Linkage Experience." Suicide and Life-Threatening Behavior 19 (Spring 1989), 78-89. Strategies for studying suicide and suicidal behavior.

Ewoldt, Harold F. Jane Boyd and Her Times. Cedar Rapids: Jane Boyd Community House, 1988. 77 pp. Cedar Rapids social worker, 1869-1932.

Ferguson, Bill, with Jane Ferguson. Now There Is New Hope: The Story of New Hope Village, a Home for Disabled Adults in Carroll, Iowa. Glidden: Ferguson Publications, 1984. 79 pp.

Forman, Craig. "Iowa Volunteers Bring Food and Friendship." Food and Nutrition 18 (Fall 1988), 17-18. Polk County Commodity Supplemental Food Program.

Jacobs, Lois. Iowa Veterans Home, Marshalltown, Iowa, A Century of Service: A History of the Past to the Present, 1887-1987. Marshalltown: Iowa Veterans Homes, 1987. 46 pp.

Martinez-Brawley, Emilia E., and Joan Blundall. "Whom Shall We Help? Farm Families' Beliefs and Attitudes about Need and Services." Social Work 36 (July 1991), 315-21.

Miller, Karen M. "She's Made a Housing Project a Home." Iowan 38 (Summer 1990), 36-40, 43. Margaret Toomey, manager of Homes of Oakridge, a subsidized housing project in Des Moines.

Walsh, Tom. "An Open Door for the Wronged of a War." Iowan 38 (Spring 1990), 40-45. Japanese-Americans interned at the start of World War II helped by a Quaker-run hostel in Des Moines.

Widner, Joanne. "Food Help and Community Service Go Hand in Hand." Food and Nutrition 21 (September 1991), 25-27. Des Moines social policy.

\section{Poverty}

Davidson, Osha. "Hunting and Gathering." Progressive 52 (January 1988), 50. Can recycling by a homeless Iowan.

Ogle, Kevin. No Place to Be: Farm and Rural Poverty in America. Des Moines: Prairiefire Rural Action, 1988. 36 pp. 


\section{Community and Social Change}

Jacobsen, G. Michael, and Bonnie S. Albertson. "Social and Economic Change in Rural Iowa: The Development of Rural Ghettos." Human Services in the Rural Environment 10 (SpringSummer 1987), 58-65.

Larsen, Lawrence H. "Urban Iowa One Hundred Years Ago." Annals of Iowa 49 (Fall 1988), 445-61.

Page, Brian Kirby. "Cornbelt Industrialization and Urban Growth: An Historical Geography of Wapello County, Iowa." M.A. thesis, University of California, Berkeley, 1988. 87 pp.

Silag, Bill. "Introduction: The Social Response to Industrialization in Sioux City." Annals of Iowa 50 (Fall 1989-Winter 1990), 119-29.

\section{SOCIAL LIFE AND CUSTOMS}

\section{Family Life, Pioneer Life, Social Customs}

Branstad, Chris, comp., with text by George Mills. Recipes and Recollections from Terrace Hill. Des Moines: Terrace Hill Society, 1989. 204 pp.

Brose, David A. "Treestump Tombstones in an Iowa Cemetery." Palimpsest 70 (Summer 1989), 73-74.

Brown, Farwell T. Tilden Family Letters, Civil War Period, 1861-1865: Letters about Coming to Ames, Iowa, 1867-1869, with Letters of Related Emerson, Cooper, and Briggs Families, 1839-1924. Ames, 1989. $232 \mathrm{pp}$.

Carlson, Bruce. Me ' $n$ Wesley: And How Me 'n Wesley Made and Played with Toys from Junk We'd Find in Creeks, Cow Lots, and Woods, from 1905 to 1910. Fort Madison: Quixote Press, 1988. 142 pp.

Corbin, William E. "The Selkirk Settlers in Jones County." Manitoba Pageant 22 (Spring 1977), 10-14. Reprinted from Jones County Historical Review 2 (1976), no. 1, 1-6, no. 2, 1-4. Scotch Grove, 1837-1861.

Harte, Irving S., as told to Bruce Carlson. Iowa, "The Land Between the Vowels": Stories from 1905-1925. Sioux City: Quixote Press, 1989. $146 \mathrm{pp}$. Anecdotes of farm life and social customs.

Hein, Peg, and Kathryn Cramer. Recipes from Iowa with Love. Minnetonka, MN: Young Creations, 1982. 194 pp.

Holliday, Debra. "An Iowa Homecoming." Reader's Digest 137 (November 1990), 77-78. Winterset. 
Horton, Loren N. "Messages in Stone: Symbolism on Victorian Grave Markers." Photographs by Gerald Mansheim. Palimpsest 70 (Summer 1989), 62-72.

—. "Victorian Victuals." Palimpsest 72 (Winter 1991), 204.

Kuecker, Susan, ed. "In Good Iowa Style': The Kelsey Letters, 1848-1882." Palimpsest 72 (Fall 1991), 114-47. Letters from a Linn County family.

Living History Farms Harvest of Favorite Recipes. Des Moines: Wallace Homestead, 1985. 264 pp.

McGarry, Mae C. Pioneer Calendar of Life on an Early Iowa Homestead. 1976. 55 pp. Monroe County.

Preston, Julia A. L. "Washtub over the Sun." Palimpsest 68 (Spring 1987), 2-11. Pioneering in the Fort Dodge area.

Puckett, Susan. A Cook's Tour of Iowa. Iowa City: University of Iowa Press, 1990. $310 \mathrm{pp}$.

Riley, Glenda. "Divorce Records: Linn County, 1928-1944." Annals of Iowa 50 (Winter 1991), 787-800.

_. "Prairie Partnerships." Palimpsest 69 (Summer 1988), 52-63. Economic interdependence of members of farm families in territorial Iowa.

Shade, Joanne P. "Dinner on the Move." Americana 18 (July-August 1990), 6. Victorian house tour and progressive dinner, Dubuque County.

Swift, David. "Manna from Amana: What's Better than DownHome Cooking? Up-Farm Food!" Mother Earth News no. 107 (September-October 1987), 54-57.

Whalen, Kim, and Carmen Darland, eds. Iowa Machine Shed Presents Farm Style Cooking. Davenport: HAR Davenport, 1989. $150 \mathrm{pp}$.

Wojnar, Frances Bries. Eliza, an Iowa Pioneer. Pleasant Hill, CA: Amethyst Press of California, 1991. A novelization of the life of Eliza Korte Rowle, who pioneered in Dubuque County, based on a family history by Elizabeth Link Leitgen.

\section{Holidays}

Burkhalter, Holly. The Four Midwestern Sisters' Christmas Book. New York: Viking, 1991. $131 \mathrm{pp}$.

Christian, Rebecca. “A Warm Danish Welcome." Iowan 37 (Winter 1988), 10-15, 61. Christmas time at the Danish settlements of Elk Horn and Kimballton.

"Fourth of July: A Photographic Celebration." Palimpsest 71 (Summer 1990), 80-89. 
Horton, Loren N. "The Victorian Holiday Season." Palimpsest 72 (Winter 1991), 192-203.

"Notes and Comment." New Yorker 67 (22 July 1991), 19-20. Celebrating the Fourth of July in Iowa.

Robinson, Lauren P. "Memorial Day in the 1920s." Palimpsest 72 (Summer 1991), 83-88.

Shanley, Mary Kay. "A City's 'Merry Christmas.'" Iowan 39 (Winter 1990), 10-19. Des Moines.

- "Where 'Sinterklaas' Comes to Town." Iowan 38 (Winter 1989), 10-15, 64-66. Pella.

Whye, Mike. "A Farm Family Christmas." Iowan 40 (Winter 1991), 12-21. Wright family from near Glenwood.

\section{Fairs and Festivals}

Christian, Rebecca. "Fair Portraits." Iowan 36 (Summer 1988), 31-36. Iowa State Fair.

Erickson, Lori. "Where the Fun's Old-Fashioned.". Iowan 38 (Fall 1989), 35-38. Kalona's annual Fall Festival.

Horton, George A. "Britt's First Convention." Palimpsest 70 (Summer 1989), 87-92. Hobo convention.

Iowa State Fair: Award Winning Recipes. Des Moines: Iowa State Fair, 1986. $286 \mathrm{pp}$.

Kaplan, Steve. "Hallelujah, I'm a Bum." Travel-Holiday 170 (November 1988), 96. Hobo convention in Britt.

Roberts, Charles W. "Show Time for a Vanished Past." Iowan 36 (Summer 1988), 14-19, 46. Midwest Old Threshers Reunion, Mt. Pleasant.

Whye, Mike. "Blakesburg:" Iowan 36 (Summer 1988), 50-58. Air Power Museum Reunion.

\section{Clubs and Social Organizations}

Arrington, Keith. Freemasonry in Iowa: An Historical Narrative. Highland Springs, VA: Anchor, 1989. 124 pp.

Juchems, Betty, Lillian Krekow, and Doris Vezina, comps. History of GFWC Iowa Federation of Women's Clubs, 1893-1988. 1988. 100 $\mathrm{pp}$.

Mitigwa Lodge History Book. Des Moines: Mitigwa Lodge 450, MidIowa Council BSA, 1988. 39 pp.

Nelson, Doris. The Iowa Association of Long Beach: A Brief History. Long Beach, CA, n.d. 25 pp. 
Uncommon People and an Extraordinary Place: The Outing, Clear Lake, Iowa, 1895-1975. Clear Lake: Clear Lake Outing Club, 1975. 59 pp.

\section{TRANSPORTATION}

\section{General}

Seventy-five Years on the Move!: Iowa Department of Transportation, 1913-1988. Ames, 1988. $71 \mathrm{pp}$.

Thompson, William H. Transportation in Iowa: A Historical Summary. Ames: Iowa Dept. of Transportation, 1989. 315 pp.

\section{Automobiles and Roads}

Hays, R. Allen. "State-Local Relations in Policy Implementation: The Case of Highway Transportation in Iowa." Publius 18 (1988), 79-95.

Hokanson, Drake. The Lincoln Highway: Main Street across America. Iowa City: University of lowa Press, 1988. $175 \mathrm{pp}$.

Johnson, William M. "The Swellest Car Built': A 1903 Cadillac." Palimpsest 72 (Fall 1991), 106-13.

Stevens, Peter F. "Des Moines: Birthplace of the Automobile?" Iowan 38 (Winter 1989), 58-60. The first battery-powered car.

\section{Aviation}

Dee, Emily. Souls on Board: Responses to the United Flight 232 Tragedy. Sioux City: Loess Hills Press, 1990. 173 pp. Plane crash in Sioux City.

Whye, Mike. "He's a Legend in the Air." Iowan 38 (Winter 1989), 44-51. Aden B. Livingston, Cedar Falls aviator.

\section{Railroads}

Beranek, James. Inventory of Railroad Structures in Iowa as Represented in the Photograph Collection of the State Historical Society of Iowa, Iowa City. Iowa City: State Historical Society of Iowa, 1990.

Garrett, Evan. “My Milwaukee.” Palimpsest 70 (Fall 1989), 156-60. Memories of the Chicago, Milwaukee, St. Paul \& Pacific Railroad in North English. 
Grant, H. Roger. "The Diagonal': The Story of an Iowa Shortline Railroad of the 1880s." Annals of Iowa 48 (Winter/Spring 1987), 378-87. The Wisconsin, Iowa and Nebraska Railroad.

- "Railroaders and Reformers: The Chicago \& North Western Encounters Grangers and Progressives." Annals of lowa 50 (Winter 1991), 772-86.

Hastings, Philip R. Remember the Rock. Andover, NJ: Andover Junction Publications, 1987. 47 pp. Rock Island Railroad.

Heckman, Charles A. "Establishing the Basis for Local Financing of American Railroad Construction in the Nineteenth Century: From City of Bridgeport v. The Housatonic Railroad Company to Gelpcke v. City of Dubuque." American Journal of Legal History 32 (July 1988), 236-64. Includes Gelpcke case, decided in 1864, and other Iowa bond cases.

Hilton, George W. American Narrow Gauge Railroads. Stanford, CA: Stanford University Press, 1990. 580 pp. Iowa, pp. 394-99.

Hofsommer, Don L. "To an Oasis among the Cornfields." Railroad History no. 163 (1990), 74-87. Railroad building into the lake country in Dickinson County in the late nineteenth century.

"Last Train to Iowa." Time 134 (4 December 1989), 49. Chinese company's last steam locomotive comes to Iowa.

Lotz, David E. Burlington, Iowa: Heart of the CBEQ. LaGrange, IL: Burlington Route Historical Society, 1991. 123 pp. Special issue of Burlington Bulletin, 23.

Lotz, David, and Charles Franzen. Rails to a County Seat. Washington, IA, 1989. 60 pp. Burlington, Milwaukee, Rock Island and other railroads in Washington County, 1858-1989.

Plous, F. K., Jr. "What's Different about the Iowa Interstate?" Railway Age 189 (January 1988), 40-43.

Seidel, David. Fremont, Elkhorn \& Missouri Valley R.R. Co. Columbus, NE: Harbor Mist Publications, 1988. 116 pp.

Silag, William. "The Conquest of the Hinterland: Railroads and Capitalists in Northwest Iowa after the Civil War. Annals of Iowa 50 (Spring 1990), 475-506.

\section{Stagecoaches}

Kirkpatrick, Inez E. Tavern Days in the Hawkeye State. David City, NE: South Platte Press, 1987. 304 pp. Stagecoach routes across southern Iowa. 


\section{Buses}

Walsh, Margaret. "Minnesota's 'Mr. Bus': Edgar F. Zelle and the Jefferson Highway Transportation Company." Minnesota History 52 (Winter 1991), 307-22. Bus line with considerable lowa mileage and many lowa stations.

\section{WARTIME AND MILITARY LIFE}

\section{Before 1832}

Jackson, Donald. Old Fort Madison, 1808-1813: The Story of a Military Outpost on the Mississippi Frontier. Fort Madison: Old Fort Commission, 1990. 62 pp.

Roberts, Robert B. Encyclopedia of Historic Forts: The Military, Pioneer, and Trading Posts of the United States. New York: Macmillan, 1988. 894 pp. "Iowa," pp. 283-89.

\section{Black Hawk War, 1832}

Eckert, Allan W. Twilight of Empire: A Narrative. Boston: Little, Brown, 1988. 587 pp.

Efflandt, Lloyd H. Lincoln and the Black Hawk War. Rock Island, IL: Rock Island Arsenal Historical Society, 1991. 63 pp.

\section{$1833-1860$}

Acton, Richard. "An Iowan's Death at Harpers Ferry." Palimpsest 70 (Winter 1989), 186-97. Steward Taylor of West Liberty.

\section{Civil War and Indian Wars, 1861-1866}

Anderson, Donald M. Grandfather and Company C, 19th Regiment, Washington, Iowa, 1862-1865. Dane, WI, 1988. 37 pp.

Byers, Samuel H. M. "How Men Feel in Battle." American History Illustrated 22 (April 1987), 10-17. Fifth Iowa Volunteers at Corinth and Vicksburg.

Clark, Charles B., and Roger B. Bowen. University Recruits, Company C: 12th Iowa Infantry Regiment. Elvaston, PA: Mennonite Family History, 1991.

Crosson, David. "The Martinet and the Mob: Federal Authority and Local Control of the First Iowa Volunteer Cavalry in the Civil War." Annals of Iowa 49 (Spring 1989), 639-60. 
Davis, Kathleen, ed. Such Are the Trials: The Civil War Diaries of Jacob Gantz. Ames: Iowa State University Press, 1991. 136 pp.

Gaston, Ephraim Cullen, with material added by Mark William McGinnis. The Civil War Diary of Ephraim Cullen Gaston. 217 pp. 33rd Iowa Infantry Regiment.

Goode, Philip H. "My Dear Wife': A Soldier's Letters." Transcribed by Edward Vollertsen. Palimpsest 72 (Summer 1991), 68-69.

- "'A Pretty Hard Business': The Civil War Diary of Philip H. Goode." Transcribed by Edward Vollertsen. Palimpsest 72 (Summer 1991), 51-67.

Graber, John W. “One Man's Civil War." Minnesota History 52 (Winter 1990), 144-45. John George Bauer, 5th Iowa Cavalry.

Harwood, Edith W. "GAR Campfires." Palimpsest 70 (Spring 1989), 14-17. Civil War veterans, Wapello.

Lee, George R. "The Wagonmaster's Letter." Civil War Times Illustrated 27 (1988), 30-33. Letter written in 1863 by Lee to his friend Jim Nesbitt in Iowa, describing the army's march through Mississippi following the Battle of Vicksburg.

Lyftogt, Kenneth L. "From Blue Mills to Columbia: Cedar Falls and the Civil War." M.A. thesis, University of Northern Iowa, 1989. 2 vols., 516 pp.

- "The Hardest Battle We Have Yet Witnessed." Palimpsest 68 (Fall 1987), 98-111. Cedar Falls soldiers leave for the Civil War, 1861.

- Left for Dixie: The Civil War Diary of John Rath. Parkersburg: Mid-Prairie Books, 1991. 100 pp.

Philbeck, Larry Gene. A Union Soldier in Arkansas, 1862-1866: Minos Miller of Iowa. 1990. $103 \mathrm{pp}$.

Robrock, David P. "The Seventh Iowa Cavalry and the Plains Indian Wars, 1861-1866." Montana 39 (Spring 1989), 2-17.

Ware, Eugene F. The Lyon Campaign in Missouri: Being a History of the First lowa Infantry. . . 1907. Reprint. Iowa City: Press of the Camp Pope Bookshop, 1991. 383 pp.

\section{Spanish-American War, 1898}

McDaniel, George W. "Martial Sons of Martial Sires." Palimpsest 70 (Spring 1989), 32-48. Company D of Washington, Iowa. 


\section{$1900-1941$}

Derr, Nancy. "Lowden: A Study of Intolerance in an Iowa Community During the Era of the First World War." Annals of Iowa 50 (Summer 1989), 5-22.

Grover, Timothy. "Camp Dodge." Iowan 36 (Winter 1987), 28-35, 59-62. Soldiers in World War I.

Patton, Gerald W. War and Race: The Black Officer in the American Military, 1915-1941. Westport, CT: Greenwood Press, 1981. 214 pp. Originally Ph.D. diss., University of Iowa, 1978. Chap. 3, "Fort Des Moines: Operations and Preparations," pp. 54-79.

\section{World War II, 1941-1945}

Andrews, Clarence. "Sheldon, Iowa, During World War II." Palimpsest 70 (Fall 1989), 146-55.

Ankrum, Homer. Dogfaces Who Smiled Through Tears: The 34th Red Bull Infantry Division and Attached 100th (Hawaiian) Battalion and 442nd "Go For Broke" Regimental Combat Team in WWII: A Chronicle of Heartbreaks, Hardships, Heroics, and Humor of the North African and Italian Campaigns. Lake Mills: Graphic Publishing, 1987.

Christian, Rebecca. "If We Go Down, We'll All Go Together.'" Iowan 37 (Winter 1988), 26-31, 54-55. The five Sullivan brothers of Waterloo.

Earley, Charity A. One Woman's Army: A Black Officer Remembers the WAC. College Station: Texas A \& M University Press, 1989. 218 pp. Fort Des Moines, pp. 15-126.

Green, Anne Bosanko. One Woman's War: Letters Home from the Women's Army Corps, 1944-1946. St. Paul: Minnesota Historical Society Press, 1989. 308 pp. Chap. 1, "Fort Des Moines, Iowa, 3 October to 8 December 1944," pp. 13-53.

- "Private Bosanko Goes to Basic: A Minnesota Woman in World War II." Minnesota History 51 (Fall 1989), 246-58. WAC training at Fort Des Moines.

Harten, Lucille B. "Life as a WAC: The Story of Louise Parkin." Rendezvous 22 (1987), 87-89. Fort Des Moines.

Jackson, Donald. Torokina: A Wartime Memoir, 1941-1945. Ames: Iowa State University Press, 1989. 154 pp. Noncombat experiences in the South Pacific.

Jones, Charles L. The Water and the Rock. 160 pp. Prisoner of war experiences.

Obye, Charles H. All Expenses Paid. Glendale, AZ, n.d. 98 pp. European WWII experiences of soldier from Mt. Vernon area. 
Willis, Donald J. The Incredible Year. Ames: Iowa State University Press, 1988. $174 \mathrm{pp}$. Pleasantville soldier's experiences, 1944-1945.

\section{Vietnam War, 1963-1974}

Day, George E. Return with Honor. Mesa, AZ: Champlin Museum Press, 1989. 258 pp. Prisoner of war experiences.

Seddon, James D. Morning Glories among the Peas: A Vietnam Veteran's Story. Ames: Iowa State University Press, 1990. 156 pp.

\section{WOMEN}

Ankerloo, Bengt. "Agriculture and Women's Work: Directions of Change in the West, 1700-1900." Journal of Family History 4 (Summer 1979), 111-20. Includes Hamilton County, 1870-1900.

Beran, Janice A. "Daughters of the Middle Border: Iowa Women in Sport and Physical Activity, 1850-1910." Iowa State Journal of Research 62 (November 1987), 161-81.

Bunkers, Suzanne L. "Faithful Friend': Nineteenth-Century Midwestern American Women's Unpublished Diaries." Women's Studies International Forum 10 (1987), 7-17.

Christian, Rebecca. "A Few 'Firsts' for Phoebe." Iowan 37 (Summer 1989), 6-9, 62. Phoebe Sudlow, first woman city superintendent of public schools in the U.S.

Draper, Ruth Anne, Bettie McKenzie, and Elizabeth Richards, eds. Women of Montgomery County, Iowa. Red Oak, 1982. 77 pp.

Drum, Sue, and H. Ellen Whiteley. Women in Veterinary Medicine: Profiles of Success. Ames: Iowa State University Press, 1991. $286 \mathrm{pp}$. Includes three Iowans.

Fink, Deborah, and Dorothy Schwieder. "Iowa Farm Women in the 1930s: A Reassessment." Annals of Iowa 49 (Winter 1989), 570-90.

Jellison, Katherine. "Farm Women in American History: A Note on Sources Available in Washington, D.C." Annals of Iowa 51 (Fall 1991), 168-77.

- "Sunshine and Rain in Iowa: Using Women's Autobiography as a Historical Source." Annals of Iowa 49 (Winter 1989), 591-99.

King, Elizabeth G. "Women in Iowa Legislative Politics." In A Portrait of Marginality: The Political Behavior of the American Woman, edited by Marianne Githers and Jewel L. Prestage, 284-303. New York: David McKay, 1977. 
Lensink, Judy Nolte. "Expanding the Boundaries of Criticism: The Diary as Female Autobiography." Women's Studies 14 (1988), 39-53. Focuses on the diary of Emily Hawley Gillespie, a Delaware County farm woman.

- "A Secret to Be Burried": The Diary and Life of Emily Hawley Gillespie, 1858-1888. Iowa City: University of Iowa Press, 1989. 472 pp. Originally a Ph.D. diss., University of Iowa, 1987, titled "My Only Confident': The Diary of Emily Hawley Gillespie."

McKenzie, Bettie, ed. They Didn't Have Perma Press: Women and the Changing Times: Women's Stories from Montgomery County, Iowa. Creston: Southwestern Community College Area XIV, 1989. 355 pp.

Pounds, Diana. "Suffragists, Free Love, and the Woman Question." Palimpsest 72 (Spring 1991), 2-15.

Sciancalepore, Donna M. "The Contribution of Working Women in Waterloo during World War II." M.A. thesis, University of Northern Iowa, 1989. $87 \mathrm{pp}$.

Simonis, Doris A., comp. Iowa Women in Science. Iowa City: Science Education Center, University of Iowa, 1980. $96 \mathrm{pp}$.

Stevens, Peter F. "When the Women Came to Des Moines." Iowan 36 (Spring 1988), 44-47. Suffragists' meeting in 1888 to choose a presidential ticket.

Stone, Marianne. "Mehitable Woods." Iowan 37 (Fall 1988): 5-8. Fairfield Civil War hero.

Whitehead, Vivian B., comp. Women in American Farming: $A$ List of References. Davis, CA: Agricultural History Center, University of California, 1987. 104 pp.

Willie-Sutton, Mary. "Survey of Iowa Farm Women: Paid and Unpaid Work Activity." M.A. thesis, University of Iowa, 1987. $128 \mathrm{pp}$.

Yanney, Linda J. "The Practical Revolution: An Oral History of the Iowa City Feminist Community, 1965-1975." Ph.D. diss., University of lowa, 1991. $211 \mathrm{pp}$.

Yousefi, Rachelle C. "Voting Behavior of Women in the Iowa House of Representatives." M.A. thesis, University of Northern Iowa, 1989. $87 \mathrm{pp}$.

Zeff, Eleanor, E. "Women in the Iowa Legislature: A 1986 Update." Iowa State Journal of Research 62 (November 1987), 329-36. 
Copyright of Annals of Iowa is the property of State of Iowa, by \& through the State Historical Society of Iowa and its content may not be copied or emailed to multiple sites or posted to a listserv without the copyright holder's express written permission. However, users may print, download, or email articles for individual use. 